\title{
Anaerobic oxidation of methane: an underappreciated aspect of methane cycling in peatland ecosystems?
}

\author{
K. A. Smemo ${ }^{1, *}$ and J. B. Yavitt ${ }^{1}$ \\ ${ }^{1}$ Department of Natural Resources, Cornell University, Ithaca, New York, USA \\ *now at: The Holden Arboretum, Kirtland, Ohio and The Department of Biological Sciences, Kent State University, \\ Kent, Ohio, USA
}

Received: 30 August 2010 - Published in Biogeosciences Discuss.: 29 October 2010

Revised: 11 March 2011 - Accepted: 16 March 2011 - Published: 24 March 2011

\begin{abstract}
Despite a large body of literature on microbial anaerobic oxidation of methane (AOM) in marine sediments and saline waters and its importance to the global methane $\left(\mathrm{CH}_{4}\right)$ cycle, until recently little work has addressed the potential occurrence and importance of AOM in non-marine systems. This is particularly true for peatlands, which represent both a massive sink for atmospheric $\mathrm{CO}_{2}$ and a significant source of atmospheric $\mathrm{CH}_{4}$. Our knowledge of this process in peatlands is inherently limited by the methods used to study $\mathrm{CH}_{4}$ dynamics in soil and sediment and the assumption that there are no anaerobic sinks for $\mathrm{CH}_{4}$ in these systems. Studies suggest that AOM is $\mathrm{CH}_{4}$-limited and difficult to detect in potential $\mathrm{CH}_{4}$ production assays against a background of $\mathrm{CH}_{4}$ production. In situ rates also might be elusive due to background rates of aerobic $\mathrm{CH}_{4}$ oxidation and the difficulty in separating net and gross process rates. Conclusive evidence for the electron acceptor in this process has not been presented. Nitrate and sulfate are both plausible and favorable electron acceptors, as seen in other systems, but there exist theoretical issues related to the availability of these ions in peatlands and only circumstantial evidence suggests that these pathways are important. Iron cycling is important in many wetland systems, but recent evidence does not support the notion of $\mathrm{CH}_{4}$ oxidation via dissimilatory $\mathrm{Fe}(\mathrm{III})$ reduction or a $\mathrm{CH}_{4}$ oxidizing archaea in consortium with an $\mathrm{Fe}$ (III) reducer. Calculations based on published rates demonstrate that AOM might be a significant and underappreciated constraint on the global $\mathrm{CH}_{4}$ cycle, although much about the process is unknown, in vitro rates may not relate well to in situ rates, and projections based on those rates are fraught with uncertainty. We suggest electron transfer mechanisms, $\mathrm{C}$ flow and pathways, and quantifying in situ peatland AOM rates as the highest priority topics for future research.
\end{abstract}

Correspondence to: K. A. Smemo (kurt.smemo@gmail.com)

\section{Introduction}

Anaerobic oxidation of methane (AOM; per Valentine, 2002) linked to microbial sulfate reduction (SR) is thought to consume most of the methane $\left(\mathrm{CH}_{4}\right)$ produced in and diffusing through marine sediments (Reeburgh and Heggie, 1977; Valentine, 2002). The process consumes an estimated 20100 (Reeburgh, 1989) to 300 (Hinrichs and Boetius, 2002) $\mathrm{TgCH}_{4} \mathrm{yr}^{-1}$, which is equivalent to 5 to $60 \%$ of the global annual $\mathrm{CH}_{4}$ flux into the atmosphere. AOM is therefore important to the present-day global $\mathrm{CH}_{4}$ cycle, and it has been suggested that AOM played a role in the rise of atmospheric $\mathrm{O}_{2} \sim 2.4 \mathrm{Gyr}$ ago (Catling et al., 2007). Considering that atmospheric $\mathrm{CH}_{4}$ has a mass-based warming potential up to 72 times that of carbon dioxide $\left(\mathrm{CO}_{2}\right)$ and has increased considerably due to human activity (IPCC, 2007), AOM represents a potential mechanistic constraint on global warming. Despite the global significance of AOM and considerable effort to identify the exact mechanisms and organism(s) involved in marine sediment AOM (e.g. Boetius et al., 2000; Hinrichs et al., 1999; Thomsen et al., 2001), much about the process and organisms responsible remains unclear and little is known about the occurrence and importance of the process in nonmarine systems.

AOM in non-marine systems has been alluded to in a few lakes (e.g. Panganiban et al., 1979; Smith et al., 1993; Eller et al., 2005), two landfills (Bjerg et al., 1995; Grossman et al., 2002), anoxic waste slurries (Malek and Weismann, 1988), a contaminated aquifer (Smith et al., 1991), and flooded-rice paddies (Miura et al., 1992; Murase and Kimura, 1994b), but much of the evidence is anecdotal in nature and strong evidence for AOM in freshwater systems has been limited. Work by Islas-Lima et al. (2004) and Raghoebarsing et al. (2006) has demonstrated that AOM in some freshwater systems is linked to denitrification and dentrifying bacteria, which provides an energetically favorable alternative to marine AOM linked to SR. Further work has

Published by Copernicus Publications on behalf of the European Geosciences Union. 
suggested that AOM can be carried out by denitrifying bacteria in the absence of an archeal consortium (Ettwig et al., $2008)$ and that this process might be linked to nitrite $\left(\mathrm{NO}_{2}^{-}\right)$ reduction and the production of oxygen $\left(\mathrm{O}_{2}\right)$ as an electron acceptor (Ettwig et al., 2010); hence, implying aerobic metabolism under anoxic conditions.

Many freshwater wetlands and peatlands provide habitat for methane-producing microorganisms (methanogens), and these ecosystems collectively are the most significant source of atmospheric $\mathrm{CH}_{4}$ (Mikaloff Fletcher et al., 2004). Wetlands in northern latitudes $\left(>45^{\circ} \mathrm{N}\right.$; northern peatlands), in particular, cover just $3 \%$ of the continents, yet they represent a significant fraction of this $\mathrm{CH}_{4}$ flux and are a massive and continued sink for atmospheric $\mathrm{CO}_{2}$ (Limpens et al., 2008; Nilsson et al., 2008), storing between 270 and $370 \mathrm{TgC}$ (Turunen et al., 2002), which is comparable to nearly half of the $C$ in the atmosphere (IPCC, 2007). A net annual carbon balance near zero and high latitude location also suggest that these systems are sensitive to environmental changes (Gorham, 1991). For example, decomposition, C storage, and $\mathrm{CH}_{4}$ emission in peatlands are sensitive to both warming and precipitation patterns (Updegraff et al., 2001), and climate warming is expected to be more pronounced at higher latitudes. Nevertheless, our understanding of peatland $\mathrm{CH}_{4}$ emissions is often reduced to the simple balance between anaerobic methanogenesis and aerobic $\mathrm{CH}_{4}$ oxidation (Fig. 1), and studies addressing potential alternative consumptive fates of $\mathrm{CH}_{4}$ in anoxic wetland soils and in peatlands have been lacking. Previous research has argued - but without experimental data - that AOM is unimportant in such systems (Segers, 1998; Topp and Pattey, 1997).

Recent evidence presented by Smemo and Yavitt (2006, 2007) challenges this assumption and suggests a potentially important role for AOM in a variety of peatland ecosystems. They found that AOM occurs simultaneously with methanogenesis, can consume a significant amount of gross $\mathrm{CH}_{4}$ production, appears to depend upon $\mathrm{CH}_{4}$ accumulation to large concentrations in peat porewater, and can constrain atmospheric $\mathrm{CH}_{4}$ flux under certain conditions. AOM might be more common than previously thought, but the relationship between AOM in peatlands and the known pathways (SR, denitrification, or $\mathrm{Fe} / \mathrm{Mn}$ reduction) is unclear. The focus of this paper is to analyze evidence for AOM in relation to peatland $\mathrm{CH}_{4}$ cycling and the global $\mathrm{CH}_{4}$ cycle, address uncertainties pertaining to the known mechanisms and pathways, and propose future directions. In addition, we briefly review past evidence from marine and other freshwater systems to provide mechanistic insights into AOM in peatland ecosystems.

\section{Biogeochemistry and electron acceptors}

In marine sediments, sulfate $\left(\mathrm{SO}_{4}^{2-}\right)$ is the most common oxidant used in organic matter decomposition. $\mathrm{As}_{4}^{2-}$ is reduced and concentrations are depleted with depth, $\mathrm{CH}_{4}$

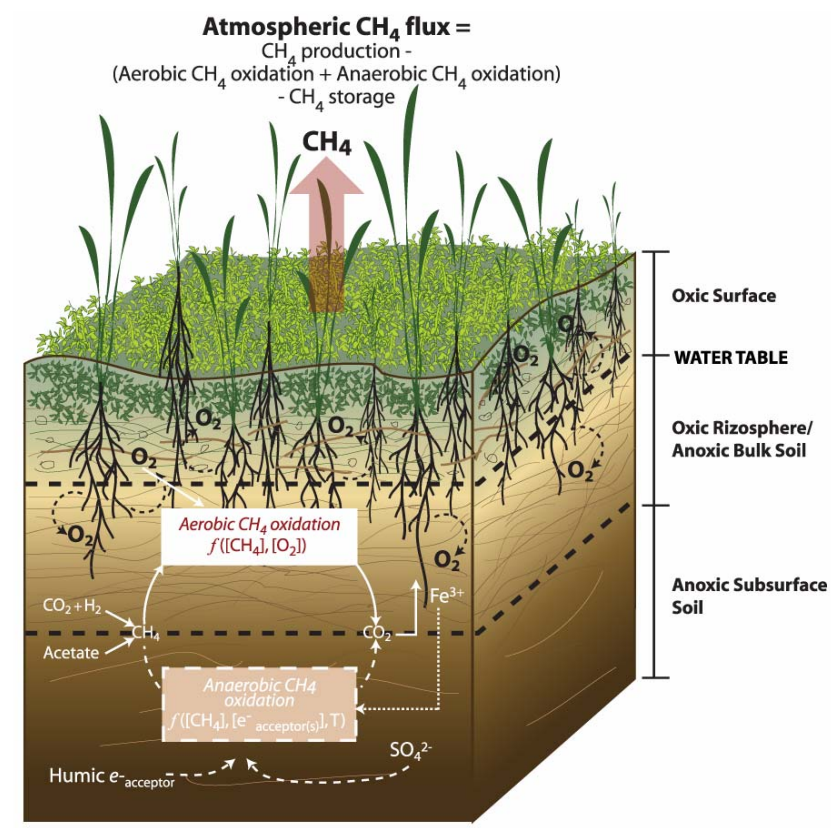

Fig. 1. Conceptual model of $\mathrm{CH}_{4}$ cycling in the profile of Sphagnum sp. and Carex sp. covered peat-forming wetland that depicts the relationship between water table depth, plant rooting zone, and redox status. Solid boxes and arrows represent known processes and controls on $\mathrm{CH}_{4}$ flux, dashed black arrows represent $\mathrm{O}_{2}$ flux from plant roots, and dashed white boxes and arrows represent recently quantified or hypothesized processes and controls. The proposed equation at the top illustrates the sum of the processes and factors controlling net atmospheric $\mathrm{CH}_{4}$ flux rates from wetland ecosystems.

production (methanogenesis) becomes the most common organic matter decomposition process after that. SR outcompetes methanogenesis for most substrates based upon thermodynamic and kinetic reasons, and depth distribution profiles of $\mathrm{SO}_{4}^{2-}$ and $\mathrm{CH}_{4}$ clearly show the transition zone where decomposition processes shift from SR to methanogenesis. However, geochemical gradients in sediments indicate that $\mathrm{CH}_{4}$ concentrations decrease rapidly in the zone of SR (Barnes and Goldberg, 1976; Reeburgh, 1976), and studies (see Valentine (2002) for a more complete list of references) indicate that the remaining $\mathrm{CH}_{4}$ pool is highly enriched with respect to ${ }^{13} \mathrm{C}$, which is consistent with high C fractionation during AOM (Alperin and Reeburgh, 1985). Tracer measurements using ${ }^{14} \mathrm{CH}_{4},{ }^{13} \mathrm{CH}_{4}$, and ${ }^{35} \mathrm{SO}_{4}^{2-}$ provide further confirmation that $\mathrm{AOM}$ is linked to $\mathrm{SR}$ and potentially sulfate-reducing bacteria (SRB) that utilize $\mathrm{CH}_{4}$ as a carbon or energy source (Reaction 1).

$\mathrm{CH}_{4}+\mathrm{SO}_{4}^{2-} \rightarrow \mathrm{HCO}_{3}^{-}+\mathrm{HS}^{-}+\mathrm{H}_{2} \mathrm{O}$

Other studies have suggested that SRB did not carry out AOM directly, but rather a consortium with unknown organisms and SRB was involved (Alperin and Reeburgh, 1985; Hoehler et al., 1994; Sørensen, 1988). 
More recent studies have focused on dynamic $\mathrm{CH}_{4}$ seeps in marine environments, where archaeal specific lipid biomarkers (Hinrichs et al., 1999; Michaelis et al., 2002; Pancost et al., 2000) and molecular studies (Boetius et al., 2000; Orphan et al., 2001; Thomsen et al., 2001) suggest that AOM is carried out by a consortium between an organism(s) phylogenetically related to methanogens (Hallam et al., 2004) in a syntrophic relationship with SRB. A similar consortium from sediments near $\mathrm{CH}_{4}$ hydrate was cultured in vitro with continuous supplies of $\mathrm{CH}_{4}$ and $\mathrm{SO}_{4}^{2-}$ (Nauhaus et al., 2007). AOM rates increased from 20 to $230 \mu$ mol day $^{-1}$ and the number of microbial aggregates increased 10-fold. However, at experimental conditions (1.4 $\mathrm{Mpa} \mathrm{CH}_{4}$ and sea water $\mathrm{SO}_{4}^{2-}$ concentrations) consortia growth was slow, with a doubling time of $\sim 7$ months. This evidence led researchers to revisit studies by Zehnder and Brock $(1980,1979)$ and Hoehler et al. (1994) suggesting that AOM could proceed via methanogenesis "operating in reverse". This mechanism was further substantiated by recent work showing that the AOM "back reaction" is actually catalyzed by methylcoenzyme $\mathrm{M}$ reductase (MCR), the key enzyme in methanogenesis (Scheller et al., 2010).

Such compelling evidence helps explain the occurrence and importance of AOM in marine systems and anoxic $\mathrm{SO}_{4}^{2-}$-rich waters, yet many uncertainties regarding the distribution and mechanism of the process remain (Alperin and Hoehler, 2010; Caldwell et al., 2008). For instance, the organisms responsible have not been isolated in pure culture, and recent evidence has demonstrated that marine AOM is coupled to a greater variety of electron acceptors, such as $\mathrm{Fe}$ and $\mathrm{Mn}$ (Beal et al., 2009), and that AOM rates can be substantial at lower $\mathrm{SO}_{4}^{2-}$ concentrations $(<1 \mathrm{mM})$ than previously thought (Beal et al., 2011). There also is evidence suggesting that some anaerobic bacteria, although linked to $\mathrm{NO}_{3}^{-}$reduction and not $\mathrm{SR}$, can oxidize $\mathrm{CH}_{4}$ in the absence of a syntrophic relationship (Ettwig et al., 2009). Moreover, $\mathrm{H}_{2}$, formate, and acetate are the most likely molecules involved in interspecies electron transfer from methanogenic archaea to SRB (Thauer and Shima, 2008). Evidence suggests that the some of these electron donors can stimulate SRB in freshwater systems (e.g. Scholten et al., 2002; Schönheit et al., 1982; Westermann and Ahring, 1987), but not the SRB involved in AOM in marine sediments. Sørensen et al. (2001) argue that interspecies $\mathrm{H}_{2}$ transfer is thermodynamically constrained and therefore unlikely to be important in marine sediments. For a more detailed discussion of $\mathrm{H}_{2}$-syntrophy and alternative mechanisms refer to Valentine and Reeburgh (2000), Valentine (2002), and Caldwell et al. (2008).

AOM in peatlands has remained somewhat of an enigma. Not only has evidence for the process been lacking, but the terminal electron acceptor has remained elusive. Recent evidence provides strong support for the occurrence of AOM in peat soils (Smemo and Yavitt, 2007), yet conclusive ev-
Table 1. Gibbs Free Energy $\left(\Delta G^{\prime}\right)$ for AOM across a trophic gradient of peatland types using various inorganic electron acceptors. Calculations assume standard conditions and the following peat porewater ion concentrations. Rich fen values ${ }^{1}:\left[\mathrm{CH}_{4}\right]=4000 \mu \mathrm{M}$; $\left[\mathrm{HCO}_{3}^{-}\right]=20 \mathrm{mM} ;\left[\mathrm{H}_{2}\right]=400 \mathrm{nM} ;\left[\mathrm{NO}_{3}^{-}\right]=1.6 \mu \mathrm{M} ;$ [soluble $\mathrm{Fe}(\mathrm{III})]=0.5 \mathrm{mM}$; [soluble $\mathrm{Fe}(\mathrm{II})]=10 \mathrm{mM} ;\left[\mathrm{SO}_{4}^{2-}\right]=0.2 \mathrm{mM}$; $\left[\mathrm{HS}^{-}\right]=30 \mu \mathrm{M}$. Poor/Intermediate fen values ${ }^{2}:\left[\mathrm{CH}_{4}\right]=400 \mu \mathrm{M}$; $\left[\mathrm{HCO}_{3}^{-}\right]=2 \mathrm{mM} ;\left[\mathrm{H}_{2}\right]=20 \mathrm{nM} ;\left[\mathrm{NO}_{3}^{-}\right]=3.5 \mu \mathrm{M} ;$ [soluble $\mathrm{Fe}(\mathrm{III})]=0.5 \mathrm{mM}$; [soluble $\mathrm{Fe}(\mathrm{II})]=100 \mu \mathrm{M} ;\left[\mathrm{SO}_{4}^{2-}\right]=100 \mu \mathrm{M}$; $\left[\mathrm{HS}^{-}\right]=20 \mu \mathrm{M}$. Bog values ${ }^{3}:\left[\mathrm{CH}_{4}\right]=400 \mu \mathrm{M} ;\left[\mathrm{HCO}_{3}^{-}\right]=2 \mathrm{mM}$; $\left[\mathrm{H}_{2}\right]=20 \mathrm{nM} ;\left[\mathrm{NO}_{3}^{-}\right]=0.5 \mu \mathrm{M} ;[$ soluble $\mathrm{Fe}(\mathrm{III})]=5 \mu \mathrm{M} ;[$ soluble $\mathrm{Fe}(\mathrm{II})]=20 \mu \mathrm{M} ;\left[\mathrm{SO}_{4}^{2-}\right]=5 \mu \mathrm{M} ;\left[\mathrm{HS}^{-}\right]=2 \mu \mathrm{M}$.

\begin{tabular}{lccc}
\hline & \multicolumn{3}{c}{$\Delta \mathrm{G}^{\prime}\left(\mathrm{kJ} \mathrm{rxn}^{-1}\right)$} \\
\cline { 2 - 4 } $\mathrm{e}^{-}$acceptor & Roor/Intermediate \\
\hline $\mathrm{NO}_{3}^{-}$ & -372.8 & -337.1 & -362.0 \\
$\mathrm{Fe}(\mathrm{OH})_{3}$ & -115 & -123.0 & -123.0 \\
$\mathrm{SO}_{4}^{2-}$ & -19.3 & -16.3 & -14.6 \\
\hline
\end{tabular}

1 values from unpublished data for Michigan Hollow Fen (Smemo and Yavitt, 2006; 2007), Smemo and Yavitt (2006), and Keller and Bridgham (2007). ${ }^{2}$ values derived from Hornibrook et al. (2009), Keller and Bridgham, (2007), Küsel et al. (2008), and Loy et al. (2004). ${ }^{3}$ values derived from Beer and Blodau (2007), Billet and Moore (2008), Blodau et al. (2007a, 2007b), and Steinmann and Shotyk (1997a, 1997b).

idence describing the mechanism and electron acceptor has not been reported. Peatlands are organic matter rich, metal poor, and often acidic (Damman, 1978). Metal concentrations are lower in peat than in mineral soils, and peat microbial communities have unique adaptations for scavenging metals. This may even be the case in less acidic peatlands like some fens, where organic matter binds metals tightly (e.g. Fe and Mn oxides rapidly reduced). Because known AOM pathways involve high concentrations of metals (as both enzymatic components and electron acceptors), which likely do not exist in most peatlands, these pathways might be quantitatively unimportant in peat soils.

Sulfate-dependent AOM is barely favorable thermodynamically (Caldwell et al., 2008; Thauer and Shima, 2006; Wake et al., 1977), and the available evidence suggests that it proceeds at very slow rates even when $\mathrm{SO}_{4}^{2-}$ concentrations are large. This presents a dilemma for $\mathrm{SO}_{4}^{2-}$-dependent AOM in peatlands because $\mathrm{SO}_{4}^{2-}$ concentrations, with a few exceptions, are presumably too small for the process to be beneficial (Wieder and Lang, 1988) and calculations of the Gibb's Free Energy of $\mathrm{SO}_{4}^{2-}$-dependent AOM in a variety of peatlands with typical $\mathrm{SO}_{4}^{2-}$ concentration (Table 1) are below the threshold needed to fuel ATP generation (Schink, 1997). Beal et al. (2011) demonstrated that AOM could proceeed at $\mathrm{SO}_{4}^{2-}$ concentrations $<1 \mathrm{mM}$, but at that concentration AOM became uncoupled from SR. Past studies have suggested that AOM linked to SR occurs in flooded paddy 
soils (e.g. Murase and Kimura, 1994b), and Grossman et al. (2002) reported possible AOM in a landfill leachate plume that was likely associated with SR, but these studies used mass balance approaches and did not provide direct evidence. Smemo and Yavitt (2007) found significant reductions in net $\mathrm{CH}_{4}$ flux with additions of $\mathrm{SO}_{4}^{2-}$, but the effect was associated with suppression of gross $\mathrm{CH}_{4}$ production and not AOM stimulation.

Many peatland ecosystems do receive significant $\mathrm{SO}_{4}^{2-}$ inputs via acid deposition (Gauci et al., 2005; Wieder et al., 1992) and significant rates of SR do occur in peatlands (Dise and Verry, 2001; Keller and Bridgham, 2007), even though $\mathrm{SO}_{4}^{2-}$ concentrations remain very small compared to marine systems even under such conditions. It is possible that a complex sulfur cycle in peat soil maintains AOM linked to SR; a process that depends on a relatively constant pool of internally cycled sulfur instead of external inputs (Blodau et al., 2007a). Several potential mechanisms might drive this cycle. First, reduced sulfur compounds could be oxidized to $\mathrm{SO}_{4}^{2-}$ by aerobic sulfur-oxidizing organisms when seasonal water table fluctuations lead to oxic conditions in the surface peat, which can influence sulfur speciation and oxidation/reduction (Prietzel et al., 2009). Alternatively, $\mathrm{SO}_{4}^{2-}$ could be cycled in the oxic/anoxic interface surrounding plant roots. The highest rates of SR in flooded rice-paddy soils have been found to occur in the rhizosphere (Liesack et al., 2000), and high rates of sulfur cycling have consistently been measured in systems with low sulfur concentrations (Stubner et al., 1998). Finally, oxidation and reduction of sulfur compounds could occur under anoxic conditions (Blodau et al., 2007a) and the process could be related to an organic C electron acceptor (Heitmann and Blodau, 2006). Hence, a relatively small amount of $\mathrm{S}$ could be recycled and fuel significant organic $\mathrm{C}$ mineralization. Smemo and Yavitt (2007) measured significantly greater rates of AOM in surface peat associated with the plant rooting-zone than in deep peat that is permanently anoxic. Sulfur cycling in this zone could provide a mechanism for electron acceptor replenishment, but direct evidence was not reported.

AOM using $\mathrm{NO}_{3}^{-}$as an electron acceptor provides nearly as much free energy as aerobic $\mathrm{CH}_{4}$ oxidation (Table 1), but it proceeds by a very different mechanism than AOM linked to $\mathrm{SR}$, as redox couples with $\mathrm{NO}_{3}^{-}$are more positive than that required for reverse methanogenesis with MCR (Thauer and Shima, 2008). The mechanism remains elusive but appears to involve $\mathrm{NO}_{2}^{-}$and other nitrogen oxides as electron acceptors for the oxidation of $\mathrm{CH}_{4}$ (Ettwig et al., 2010). Although seasonal oxygenation of the peat surface can increase porewater $\mathrm{NO}_{3}^{-}$concentrations (e.g. Schmalenberger et al., 2007), this mechanism seems less probable in peatlands because, in general, low nitrification (Westbrook et al., 2006) or rapid denitrification rates (Gorham et al., 1985), fueled by organic $\mathrm{C}$ sources other than $\mathrm{CH}_{4}$, limit the availability of $\mathrm{NO}_{3}^{-}$and other nitrogen oxides in the system. For in- stance, the $\mathrm{NO}_{3}^{-}$concentrations reported in Raghoebarsing et al. (2006) are uncommon in most peat-forming systems (Eriksson et al., 2010; Gorham et al., 1985). Nitrite turnover is very rapid in peat soil, and nitrogen oxides furthermore are consumed quickly via chemodenitrification under acidic conditions (Vancleemput and Baert, 1984). Thus, chemical processes compete with biological denitrification. Recent evidence (Ettwig et al., 2010), however, does suggest that the role of $\mathrm{NO}_{3}^{-}$and $\mathrm{NO}_{2}^{-}$in peatland $\mathrm{AOM}$ needs further consideration.

It is important to also point out that $\mathrm{NO}_{3}^{-}$can function as a non-specific methanogenic inhibitor, thereby decreasing the amount of $\mathrm{CH}_{4}$ available to $\mathrm{CH}_{4}$ oxidizers. This can happen because methanogens are simply out-competed energetically, but also because denitrification intermediates such as $\mathrm{NO}_{2}^{-}$ are known to suppress methanogenesis (Kluber and Conrad, 1998; Roy and Conrad, 1999). Raghoebarsing et al. (2006) observed that $\mathrm{AOM}$ rates were greater when $\mathrm{NO}_{2}^{-}$was abundant with rates declining as $\mathrm{NO}_{2}^{-}$became exhausted. It is possible the effect was due to suppression of $\mathrm{CH}_{4}$ production and then an apparent decrease in $\mathrm{AOM}$ as $\mathrm{NO}_{2}^{-}$was used up and $\mathrm{CH}_{4}$ production increased. See Smemo and Yavitt (2007) for a discussion of $\mathrm{NO}_{3}^{-}$effects on $\mathrm{CH}_{4}$ dynamics.

Beccause $\mathrm{NO}_{3}^{-}$and $\mathrm{SO}_{4}^{2-}$ availability is limiting in many peatlands, we wonder whether Fe(III) could fuel AOM because the reaction is energetically favorable (Table 1) and the process has been demonstrated in marine sediments (Beal et al., 2009). Fe(III) is an important electron acceptor in many wetland soils (Frenzel et al., 1999; Jäckel and Schnell, 2000; Roden and Wetzel, 1996; Küsel et al., 2008) and it functions in organic C re-mineralization (Lovley and Phillips, 1986, 1988). Moreover, a recent study of $\mathrm{CH}_{4}$ cycling in ferruginous Lake Matano, Indonesia provides anecdotal evidence for AOM linked to Fe-oxides in the water column (Crowe et al., 2011). AOM was measured in the absence of both $\mathrm{NO}_{3}^{-}$ and $\mathrm{SO}_{4}^{2-}$ suggesting $\mathrm{Fe}$ as the most likely terminal electron acceptor, but direct measurements were not provided.

Iron (III) could be mechanistically linked to AOM in peatlands in a few ways. The first, based on the work of Lovley et al. (1996) and Scott et al. (1998), involves humic substances serving as intermediate electron acceptors in the transfer of electrons between Fe-reducing organisms and an acetateconsuming microorganism (e.g. Geobacter sp.). Given the inherently high humic content of many wetland soils and the availability of $\mathrm{CH}_{4}$ as a $\mathrm{C}$ source, a similar mechanism could function to oxidize $\mathrm{CH}_{4}$ (Fig. 4) and electron transfer from dissolved organic matter to ferric iron is viable (Heitmann et al., 2007; Kappler et al., 2004). The role of dissolved organic matter in electron transfer and the consequences for anaerobic metabolism is a contemporary area of inquiry and an important aspect of wetland C cycling (Heitmann et al., 2007), and humics may act as electron shuttles from oxic surface peat to deeper anoxic peat. 
It is possible that a consortium of organisms mediates AOM, much like the $\mathrm{SO}_{4}^{2-}$-dependent process, but with a Fe-reducing bacterium such as Geobacter sp. or Shewanella sp. according to Reaction 2:

$\mathrm{CH}_{4}+\mathrm{Fe}(\mathrm{OH})_{3} \rightarrow \mathrm{HCO}_{3}^{-}+\mathrm{FeCO}_{3}+3 \mathrm{H}_{2} \mathrm{O}$

Zehnder and Brock (1980) were the first to propose that an unknown metal oxide could serve as the electron acceptor for AOM, though no evidence was presented. Other authors proposed this mechanism as well (e.g. Daniel et al., 1999; Murase and Kimura, 1994b), but, besides circumstantial evidence from rice paddies (Miura et al., 1992), the only supporting data is from marine sediments (Beal et al., 2009). Smemo and Yavitt (2007) hypothesized Fe(III) as an electron acceptor based on field observations of flocculated Fe(III) in surface waters of minerotrophic peatlands, $\mathrm{Fe}^{\text {total }}$ concentrations in peat samples, and the potential for seasonal and annual re-oxidation of $\mathrm{Fe}(\mathrm{II})$. Laboratory experiments failed to exhibit any stimulation of AOM with a addition of 50 mmoles of amorphous Fe(III)-oxide, yet all of the Fe(III) additions were readily reduced in the peat $(96 \mathrm{~h}$ incubation period). Experiments were unable to determine if the form of the Fe(III) was not available to AOM organism(s), or if the addition was rapidly chemically reduced and therefore not available to an AOM organism(s). Futhermore, Keller and Bridgham (2007) studied anaerobic C cycling pathways across a peatland trophic gradient in Michigan, USA, and found that $\mathrm{Fe}$ reduction was an insignificant component of anaerobic $\mathrm{C}$ mineralization. A different result was obtained in a study of Fe reduction in an acidic fen (Küsel et al., 2008) where $\mathrm{Fe}$ reduction accounted for $27-72 \%$ of anaerobic $\mathrm{C}$ mineralization in fens receiving exogenous $\mathrm{Fe}$ and $7 \%$ with only internally cycled Fe. In a further study in the same peatlands (Reiche et al., 2008), Fe reduction was a significant process that inhibited methanogenesis. The authors also found that the addition of a methanogenic inhibitor (BES) resulted in a $45 \%$ decrease in Fe reduction, a result that could be explained by the hypothesized link between Fe reduction and reverse methanogenesis (Crowe et al., 2011). Given the importance of Fe cycling processes in many ecosystems and the potential for internal oxidation-reduction cycling of both Fe and Mn (small pools of Fe and Mn can be oxidized and reduced, and thus used to drive AOM, 100-300 times before burial in marine sediments (Beal et al., 2009), further work is needed to better understand forms of microbially available metal oxides in humic-rich environments and how they might be linked to AOM.

\section{Microbiology}

Zehnder and Brock (1979) first proposed the idea of reverse methanogenesis, and they found that nine strains of methanogens were able to produce $\mathrm{CH}_{4}$ and carry out $\mathrm{CH}_{4}$ oxidation. However, the measured oxidation accounted for
$<1 \%$ of $\mathrm{CH}_{4}$ production, and there was some question as to whether carbon monoxide contamination of the ${ }^{14} \mathrm{C}-\mathrm{CH}_{4}$ used in the oxidation assays biased the results (Miller et al., 1999). Notwithstanding, recent work by Schelller et al. (2010) demonstrated that MCR (key enzyme in methanogenesis) does indeed catalyze AOM by converting $\mathrm{CH}_{4}$ into methyl-coenzyme M. Although all methanogens have MCR, not all are capable of AOM. Furthermore, the reverse methanogenesis mechanism with MCR works when $\mathrm{SO}_{4}^{2-}$ is the ultimate electron acceptor, but $\mathrm{NO}_{3}^{-}, \mathrm{Fe}(\mathrm{III})$, or $\mathrm{Mn}(\mathrm{IV})$ availability is low in most peatlands (Damman, 1978) and it is therefore doubtful that reverse methanogenesis linked to these alternate electron acceptors is quantitatively important. Moreover, a recent study by Beal et al. (2011) demonstrated that marine $\mathrm{AOM}$ proceeds at lower $\mathrm{SO}_{4}^{2-}$ concentrations $(<1 \mathrm{mM})$ than previously thought and that at low concentrations AOM and SR are uncoupled, suggesting that AOM is not solely dependent on SR and SRB.

In marine systems, the archaeal methanogens and ANMEs fall into three phylogenetic groups; ANME-1 (with subgroups a and b) and ANME-2 (with subgroups a, b, and c) related to the Methanomicrobiales and Methanosarcinales (Boetius et al., 2000; Orphan et al., 2002), whereas ANME3 is related to Methanococcoides spp. (Knittel and Boetius, 2009). Whether these are the only members that mediate AOM is unclear. For instance, Scholten et al. (2005) reported $\mathrm{AOM}$ in an alkaline, $\mathrm{SO}_{4}^{2-}$-rich lake mediated by a SRB, whereas known ANMEs were not involved; they suggested the SRB acts alone, meaning that yet undiscovered mechanisms might exist. For peatlands, most contain a high diversity of methanogens (Cadillo-Quiroz et al., 2008); however, ANME relatives appear to be restricted to nutrient-rich, grass dominated fen peatlands, at very low numbers, and they do not appear to occur in the extensive acidic peatlands dominated by mosses and shrubs (Dettling et al., 2007).

The SRB linked to AOM in marine sediments belong to Delta-proteobacteria, in particular the genera Desulfosarcina, Desulfococcus, and Desulfobulbus (Knittel and Boetius, 2009). However, these SRB are found mostly in $\mathrm{SO}_{4}^{2-}$-rich and / or saline sediments, and are rare to absent in freshwater sediments (Miletto et al., 2008). The SRB in peat soils are poorly known and they are not members known to associate with ANME. Loy et al. (2004) found that acidic fens with low in situ $\mathrm{SO}_{4}^{2-}$ concentrations have a significant SR capacity and despite the presence of known SRB groups, they detected the presence of several novel SRB types that were unrelated to all known SRB. They suggested that these types belonged to a specialized group of SRB associated with low $\mathrm{SO}_{4}^{2-}$ environments. More recent work (Schmalenberger et al., 2007) has suggested that these previously undescribed groups are present in permanently anoxic peat and may act as fermentors in a syntrophic relationship with methanogens. However, these SRB have not been shown to reduce $\mathrm{SO}_{4}^{2-}$ and could not carry out AOM via the SR pathway. 
A facultative dissimilatory $\mathrm{Fe}(\mathrm{III})$-reducing organism that uses $\mathrm{CH}_{4}$ as a $\mathrm{C}$ or energy source also is a possible explanation for AOM in wetland soils (Fig. 4; Reaction 2), but the process was not observed in past studies of known Fe(III)reducers or in AOM studies in peat soils (Smemo and Yavitt, 2007). A study by Daniel et al. (1999) found that Fe(III) reduction can be coupled to methanol oxidation by a syntrophic relationship between Shewanella putrefacians and Clostridium sphenoides. They proposed a potentially beneficial reaction $\left(\Delta \mathrm{G}^{\circ}=-782 \mathrm{~kJ}\right.$ reaction $\left.{ }^{-1}\right)$ and claimed that this reaction would be slow due to the nature of the syntrophic relationship, but they did not account for the fact that Fe(III) is not available at $\mathrm{pH} 7.0$ in natural waters. Thus, this energy yield is unrealistic. Table 1 provides a more realistic number.

Another possible pathway relates to anaerobic ammonium $\left(\mathrm{NH}_{4}^{+}\right.$) oxidation (ANAMMOX), which is an important process in anoxic wastewaters (Jetten et al., 1999) and marine systems (Capone and Knapp, 2007; Dalsgaard et al., 2003; Dalsgaard and Thamdrup, 2002; Devol, 2003; Kuypers et al., 2003). It is plausible that ammonium oxidizing organisms may be able to utilize $\mathrm{CH}_{4}$ in addition to $\mathrm{NH}_{4}^{+}$. The two molecules are very similar, and oxygenase enzymes tend to be non-specific; in the case of aerobic environments, ammonium monooxygenase can readily utilize either $\mathrm{NH}_{4}^{+}$or $\mathrm{CH}_{4}$ depending on which is more available and methane monooxygenase has been shown to utilize $\mathrm{NH}_{4}^{+}$(Bosse et al., 1993). Evidence suggests that enzymatic pathways in anoxic environments are analogous to those in oxic environments as methane monooxygenase is involved in AOM linked to denitrification in anoxic environments (Ettwig et al., 2010). However, ANAMMOX bacteria are not known to be ubiquitous in wetland ecosystems (Zhu et al., 2010), and a genomic study of an ANAMMOX bacterium demonstrated that ammonium activation involves an enzyme unique to ANAMMOX bacteria and not a general monooxygenase (Strous et al., 2006). Recently, Zhu et al. (2010) discussed the role of ANAMMOX and AOM coupled to denitrification in wetland ecosystems as a control on $\mathrm{N}$ cycling; suggesting that $\mathrm{N}$ transformations could be a sink for $\mathrm{CH}_{4}$ in wetlands. The authors further suggested that environmental conditions for the couplings of these processes exist, but evidence is lacking and many wetlands do not have high $\mathrm{NO}_{2}^{-}$availability needed to support it. Aerobic $\mathrm{NO}_{2}^{-}$production in peat could provide a mechanism for coupling of aerobic and anaerobic processes and reveal such an AOM pathway. Smith et al. (1991) found that a $\mathrm{CH}_{4}$ tracer was readily oxidized in an anoxic aquifer with high $\mathrm{NH}_{4}^{+}$and $\mathrm{NO}_{3}^{-}$concentrations and no ambient $\mathrm{CH}_{4}$. The $\mathrm{CH}_{4}$, therefore, could have been oxidized by an anaerobic $\mathrm{NH}_{4}^{+}$oxidizing organism if that organism was biochemically able to utilize $\mathrm{CH}_{4}$ when introduced in sufficient concentrations (Richard L. Smith, USGS, Boulder, Colorado, USA, personal communication, 2000).
Finally, the role of bacterial methanotrophs, usually thought to be strictly aerobes, needs to be considered in future studies of AOM. Recent genomic insights into the methanotrophic bacteria Methylococcus capsulatus (Bath) revealed unexpected metabolic flexibility, including chemolithotrophic abilities and the ability to function at low redox potentials (Ward et al., 2004). M. capsulatus (Bath) produces enzymes usually associated with fermentative activity, and is thought to possess high molecular-weight cytochromes that are often associated with metal-ion reducing genera such as Shewanella and Geobacter. Ward et al. (2004) point out that $M$. capsulatus (Bath) could benefit from oxidizing $\mathrm{CH}_{4}$ under low oxygen conditions by physically living near or in zones where $\mathrm{CH}_{4}$ production occurs. The discovery that AOM coupled to denitrification is carried out by an oxygenic bacterium in freshwater sediments (Ettwig et al., 2010) only underscores the need to consider metabolic flexibility when studying AOM in peatlands.

\section{The Evidence for AOM}

\subsection{Non-peatland ecosystems}

Evidence for AOM in marine sediments is well-established and is based on geochemical depth-distribution profiles (e.g. Barnes and Goldberg, 1976; Reeburgh, 1976), isotopic studies (e.g. Alperin and Reeburgh, 1985), use of specific biomakers (e.g. Hinrichs et al., 1999), and molecular studies (e.g. Boetius et al., 2000). Reviews of the biogeochemical evidence can be found in Alperin and Reeburgh (1984), Valentine and Reeburgh (2000), Valentine (2002), Reeburgh (2007), and Caldwell et al. (2008).

As mentioned previously, AOM also has been observed in a few freshwater or non-marine saline systems. Panganiban et al. (1979) demonstrated that AOM consumed a portion of $\mathrm{CH}_{4}$ production in the anoxic zone of Lake Mendota (Wisconsin, USA). They found that organisms could be grown in enrichment studies using acetate and $\mathrm{CH}_{4}$ as the sole energy and carbon source, along with $\mathrm{SO}_{4}^{2-}$ as the electron acceptor. Radiocarbon tracer methods also showed that acetate was assimilated into biomass while $\mathrm{CH}_{4}$ was evolved as $\mathrm{CO}_{2}$. In a similar study, Iversen et al. (1987) quantified pelagic methanogenesis and AOM in a meromictic lake in Nevada, USA. In contrast, they found that AOM actually exceeded rates of net $\mathrm{CH}_{4}$ production in all depths studied and that little or no coupling with SR existed. The anoxic column of an Antarctic lake, covered by permanent ice, was found to oxidize almost all of $\mathrm{CH}_{4}$ production with very little escaping the water column (Smith et al., 1993). This study did not address potential electron acceptors, but oxidation did occur in the $\mathrm{SO}_{4}^{2-}$-rich zone of the water column. Recent studies in freshwater lakes have demonstrated that AOM electron acceptors are unclear and may proceed using more than one. For example, AOM occurred in the zone of 
elevated hydrogen sulfide in Lake Plußsee, Germany (Eller et al., 2005), but no mass balance data were provided. In Lake Lugano, Switzerland, Niemann et al. (2009) reported AOM biogeochemical signatures, but they concluded that the process was not driven by $\mathrm{SO}_{4}^{2-}$ and that archaea were not involved. In another Swiss lake (Lake Rotsee), Schubert et al. (2010) detected AOM at the oxycline, but $\mathrm{SO}_{4}^{2-}$ concentrations were not sufficient to account for $\mathrm{CH}_{4}$ oxidation and they concluded that $\mathrm{NO}_{3}^{-}$and/or Fe must serve as alternate electron acceptors. A study of $\mathrm{CH}_{4}$ dynamics in a ferruginous lake (Lake Matano, Indonesia) demonstrated AOM in the water column when $\mathrm{SO}_{4}^{2-}$ and $\mathrm{NO}_{3}^{-}$were not available but $\mathrm{Fe}$ oxides were abundant (Crowe et al., 2011), further implicating $\mathrm{Fe}$ as an electron acceptor in AOM..

Smith et al. (1991) used ${ }^{13} \mathrm{C}-\mathrm{CH}_{4}$ as a conservative tracer in small-scale natural-gradient test in a contaminated anoxic sand and gravel aquifer on Cape Cod, Massachusetts, USA. The aquifer was naturally $\mathrm{CH}_{4}$-deficient and no response to the addition was expected. Surprisingly, $\mathrm{CH}_{4}$ was readily oxidized to $\mathrm{CO}_{2}$ in the anoxic portion of the aquifer. Moreover, the aquifer had high nitrate $\left(\mathrm{NO}_{3}^{-}\right)$concentrations but low $\mathrm{SO}_{4}^{2-}$. Nitrate seemed the most likely electron acceptor due to the high $\mathrm{NO}_{3}^{-}$concentration and thermodynamic favorability of the reaction (Table 1).

AOM was demonstrated in tank reactors (Islas-Lima et al., 2004) and a sediment receiving agricultural runoff high in $\mathrm{NO}_{3}^{-}$(Raghoebarsing et al., 2006). Islas-Lima et al. (2004) used tank reactors with anoxic sewage sludge inoculums and $\mathrm{CH}_{4}$ as the sole electron donor. Results showed clear $\mathrm{NO}_{3}^{-}$ depletion in the presence of $\mathrm{CH}_{4}$, and depletion rates increased as $\mathrm{CH}_{4}$ concentration increased. Raghoebarsing et al. (2006) enriched a microbial consortium from anoxic canal sediment that oxidized $\mathrm{CH}_{4}$ to $\mathrm{CO}_{2}$ coupled to denitrification (see Table 1) according to Reaction 3 (from Raghoebarsing et al., 2006).

$5 \mathrm{CH}_{4}+8 \mathrm{NO}_{3}^{-}+8 \mathrm{H}^{+} \rightarrow 5 \mathrm{CO}_{2}+4 \mathrm{~N}_{2}+14 \mathrm{H}_{2} \mathrm{O}$

The consortia consisted of an archaeon that is closely related to an ANME, and a bacterium, presumably a denitrifier, that has not been cultured. Additions of ${ }^{13} \mathrm{C}$-labelled $\mathrm{CH}_{4}$ and analysis of lipid biomarkers indicated that $\mathrm{CH}_{4}$-derived $\mathrm{C}$ was incorporated into the biomass of both the bacterium and the archaeon, but to a lesser degree in the archaeon. It is not clear what is driving this pattern, but it is important to point out that the enrichment culture in this study utilized nitrite $\left(\mathrm{NO}_{2}^{-}\right)$in preference to $\mathrm{NO}_{3}^{-}$, and the process would stop in the presence of $\mathrm{CH}_{4}$ and $\mathrm{NO}_{3}^{-}$if $\mathrm{NO}_{2}^{-}$became exhausted. Recent work by Ettwig et al. (2010, 2008) showed that $\mathrm{NO}_{2}^{-}$-driven $\mathrm{AOM}$ can occur in the absence of an Archaeal partner and is carried out by an anaerobic denitrifying bacterium that oxidizes $\mathrm{CH}_{4}$ aerobically by reducing $\mathrm{NO}_{2}^{-}$ to $\mathrm{N}_{2}$ and $\mathrm{O}_{2}$. This could explain why less of the labeled $\mathrm{CH}_{4}-\mathrm{C}$ was recovered from the archaeon.
Results from landfill-leachate plumes, on the other hand, have demonstrated varying results. A leachate plume study in Grinsted, Denmark showed that $\mathrm{CH}_{4}$ disappeared completely in the zone of $\mathrm{NO}_{3}^{-}$reduction, suggesting that $\mathrm{CH}_{4}$ is an electron donor in the reduction of $\mathrm{NO}_{3}^{-}$(Bjerg et al., 1995). In contrast, Grossman et al. (2002) found that AOM consumed some of the $\mathrm{CH}_{4}$ in an Oklahoma, USA leachate plume. Hydrochemical data suggested indirectly that AOM was most likely associated with a methanogen/SRB consortium. A study of a Dutch landfill leachate plume provided evidence to suggest that that AOM linked to SR occurs within the contamination plume and AOM linked to denitrification occurs just above the plume (van Breukelen and Griffioen, 2004). However, conclusions from these studies are based on mass balance budgets and not process measurements, thus explanations other than AOM are possible.

In a more direct study of contaminant effects on $\mathrm{CH}_{4}$ production, Malek and Weismann (1988) reported cyclic shifts from net $\mathrm{CH}_{4}$ production to net anoxic $\mathrm{CH}_{4}$ consumption when they incubated fresh and saltwater biomass, petroleum, oil shale bitumen, kerogen, and sewage sludge digest with inert gas headspaces. Regardless of substrate, they recorded several cyclic episodes. No mechanisms were examined in this study, but results showed a very clear pattern in a closed system that implies a substrate limitation on AOM.

Functionally man-made wetlands, rice-paddy soils are relatively high in organic matter and represent a significant atmospheric $\mathrm{CH}_{4}$ source (Roy and Conrad, 1999). AOM has been hypothesized as an important mechanism in flooded rice paddies (Daniel et al., 1999), but published reports are few and evidence is circumstantial. Miura et al. (1992) determined that AOM linked to the reduction of $\mathrm{Fe}(\mathrm{III})$ consumed $\mathrm{CH}_{4}$ that had percolated into the subsoil. Murase and Kimura (1994a, b, c) reported similar results from incubations of rice straw amended paddy soil, but identified $\mathrm{SO}_{4}^{2-}$ leached from the plow layer as the electron acceptor in the process. Overall, AOM accounted for a small percentage of the total $\mathrm{CH}_{4}$ budget in these systems and mechanistic discussion was purely speculative. Neither of these studies measured direct consumption in response to experimental treatments, and it is possible that responses were the result of methanogenic suppression and not AOM.

\subsection{Peatland ecosystems}

Despite the importance of peatlands to global $\mathrm{C}$ and atmospheric $\mathrm{CH}_{4}$ cycles and the need for a process-based understanding of controls on wetland $\mathrm{CH}_{4}$ fluxes (Segers, 1998), our understanding of AOM as a potential $\mathrm{CH}_{4}$ sink in peatlands is rudimentary. AOM as a sink for $\mathrm{CH}_{4}$ has been alluded to in peat soils (Nedwell and Watson, 1995; Yavitt et al., 1988), but until recently no data had been presented. Rather, conceptual models of $\mathrm{CH}_{4}$ cycling in peat-forming wetlands (Fig. 1) describe $\mathrm{CH}_{4}$ fluxes as the balance between anaerobic methanogenesis and aerobic $\mathrm{CH}_{4}$ consumption 
(Whalen and Reeburgh, 2000). Indeed, many peatlands are seasonally dry at the surface, resulting in an oxic zone that $\mathrm{CH}_{4}$ must pass through; detecting AOM against such a large aerobic sink might be one reason the process is unappreciated.

Geochemical evidence for AOM, such as depth distribution profiles of electron acceptors and donors, is difficult in peat soils. The biogeochemical heterogeneity of these soils means that anaerobic processes overlap each other spatially, and zones of rhizospheric influence create spatial and temporal redox variability that further complicate studies of gross $\mathrm{CH}_{4}$ cycling rates and controls on atmospheric flux (Fig. 1). However, many studies have looked at the distribution and importance of electron acceptors in peat (e.g. Bauer et al., 2007; Deppe et al., 2010; Keller and Bridgham, 2007; Alewell et al., 2008; Knorr et al., 2009) and experimentally manipulated electron acceptor variability (e.g. Dettling et al., 2006; Dise and Verry, 2001; Vile et al., 2003) to understand controls on $\mathrm{CH}_{4}$ flux. The accepted model (as depicted in Fig. 1) suggests that methanogenesis is a primary $\mathrm{C}$ mineralization process in permanently anoxic peat, but more thermodynamically favorable reactions involving alternative electron acceptors, such as $\mathrm{SO}_{4}^{2-}$ and $\mathrm{Fe}$, suppress $\mathrm{CH}_{4}$ production and drive organic carbon oxidation in surface peat that is seasonally oxygenated around plant roots (Roden and Wetzel, 1996; Watson et al., 1997).

Although variations in $\mathrm{CH}_{4}$ flux have been explained using correlations with environmental variables (e.g. Bubier, 1995; Bubier et al., 1995a; Bubier et al., 1995b; Dise, 1993; Frolking and Crill, 1994; Mikkela et al., 1995; Moore and Knowles, 1989; Whiting and Chanton, 1993), this approach describes only a portion of the observed variation in fluxes (Segers, 1998). Process-based studies using potential $\mathrm{CH}_{4}$ production and oxidation assays (Sundh et al., 1995; Yavitt and Lang, 1990; Yavitt et al., 1997) also are limited in terms of explaining and predicting $\mathrm{CH}_{4}$ fluxes (Bellisario et al., 1999). A study by Smemo and Yavitt (2006) suggests a more complicated $\mathrm{CH}_{4}$ dynamic in some peatlands; despite the expectation of high $\mathrm{CH}_{4}$ fluxes during warm wet periods, low net potential $\mathrm{CH}_{4}$ production due to AOM (Fig. 1) might have served as an additional process controlling net fluxes and might help explain why anaerobic $\mathrm{CO}_{2}$ production often is greater than consumption of known electron acceptors (Blodau et al., 2007a; Knorr and Blodau, 2009; Watson and Nedwell, 1998).

Based on the anecdotal evidence from that study, Smemo and Yavitt (2007) used $\mathrm{CH}_{4}$-amended laboratory incubations of anoxic peat to demonstrate and quantify AOM occurrence in a peat-forming wetland in central New York State. They used specific (2-bromoethanesulfonate, BES) and nonspecific $\left(\mathrm{NO}_{3}^{-}\right)$methanogenic inhibitors, as well as both stable isotope tracer and ${ }^{13} \mathrm{C}$ fractionation techniques, which allowed them to separate production and consumption processes occurring simultaneously and estimate gross rates of

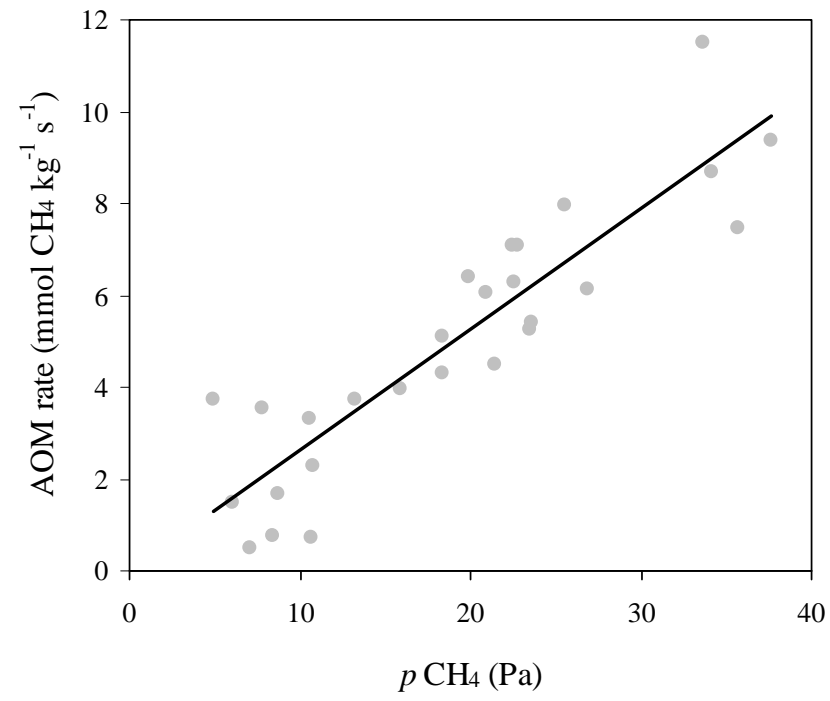

Fig. 2. Porewater $\mathrm{CH}_{4}$ concentration dependent rates of AOM. Line derived from a regression model $\left(r^{2}=0.89\right)$ of rates calculated from $\mathrm{CH}_{4}$ production data presented in Smemo and Yavitt (2007). Experiment involved homogenized peat incubated with randomly varying headspace $\mathrm{CH}_{4}$ concentrations ranging across 3 orders of magnitude. Each point represents a single incubation. $\mathrm{CH}_{4}$ concentration is presented as $\mathrm{pCH}_{4}$ of peat porewater in equilibrium with the headspace.

$\mathrm{CH}_{4}$ production and consumption. Data showed not only net AOM rates nearly as high as reported net aerobic $\mathrm{CH}_{4}$ oxidation rates (max rate of $176 \mathrm{nmol} \mathrm{kg}^{-1}$ (dry peat) $\mathrm{s}^{-1}$ and a mean rate of $17 \pm 2.6 \mathrm{nmol} \mathrm{kg}^{-1}$ (dry peat) $\mathrm{s}^{-1}(n=350)$ ), but also that $\mathrm{AOM}$ can consume a significant portion of gross $\mathrm{CH}_{4}$ production when net $\mathrm{CH}_{4}$ production is measured; suggesting that commonly used potential $\mathrm{CH}_{4}$ production assays truly measure net $\mathrm{CH}_{4}$ dynamics and not gross production and that such limitations can be overcome with the use of isotopically labeled substrates. Their results further imply that, similar to aerobic methanotrophy in peatlands (Hornibrook et al., 2009), AOM is $\mathrm{CH}_{4}$-limited (Fig. 2). Hence, AOM would not be observed in most laboratory assays in which incubations generally have no $\mathrm{CH}_{4}$ at the outset and $\mathrm{CH}_{4}$ is not allowed to accumulate for extended periods. These findings suggest, therefore, that in situ AOM occurs only where $\mathrm{CH}_{4}$ accumulates to sufficient concentrations, or that the process may be important at different times of the year. Hoehler et al. (1994), while studying AOM dynamics and mechanisms in a marine sediment, also found that $\mathrm{AOM}$ is a net sink for $\mathrm{CH}_{4}$ in the $\mathrm{SO}_{4}^{2-}$-depleted zone at $26^{\circ} \mathrm{C}$, but $\mathrm{AOM}$ proceeded in the lower portion of the SR zone at $10^{\circ} \mathrm{C}$ in the absence of $\mathrm{CH}_{4}$ production. Similar dynamics related to the seasonal relative importance of methanogenesis versus $\mathrm{AOM}$, and therefore the apparent $\mathrm{CH}_{4}$ sink strength due to $\mathrm{AOM}$, might exist in peatlands. 


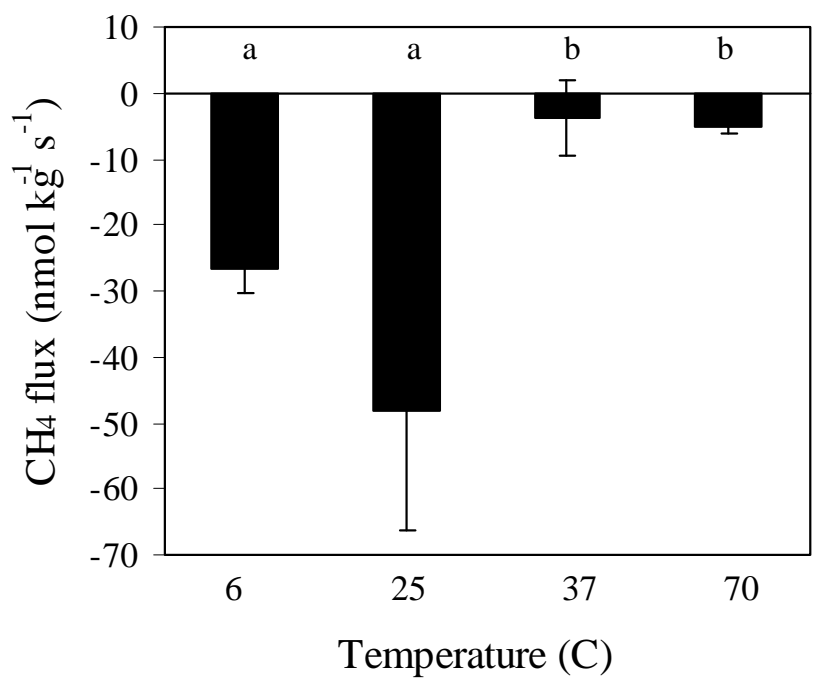

Fig. 3. Mean rates $(\mathrm{N}=4) \pm \mathrm{SE}$ of $\mathrm{CH}_{4}$ flux in anoxic peat incubations at four different temperatures using a methanogenic inhibitor (BES). Negative values denote oxidation/consumption. Different letters are significantly different at $p<0.05$

For instance, methanogens in non-marine environments have shown growth optimums at $35^{\circ} \mathrm{C}$ and methanogenesis is greatly limited at temperatures below $15^{\circ} \mathrm{C}$ (Zinder, 1993). However, evidence from deep lake sediment has shown that psychrophilic methanogens with methanogenic rate maxima at $6{ }^{\circ} \mathrm{C}$ do exist (Nozhevnikova et al., 2003). Laboratory assays using peat from a wetland in central New York State, amended with BES as a methanogenic inhibitor and headspace $\mathrm{CH}_{4}$ additions $\left(p \mathrm{CH}_{4}=\sim 500 \mathrm{~Pa}\right)$, demonstrated that net $\mathrm{AOM}$ rates were essentially zero when incubated at 70 and at $37^{\circ} \mathrm{C}$, whereas significant rates occurred at 25 and $6^{\circ} \mathrm{C}$ (Fig. 3 (data from Smemo, 2003)). It is possible that methanogenesis and AOM might have different temperature optima in peatlands, where annual temperatures vary as opposed to deep lake sediments. This opens the possibility that $\mathrm{AOM}$ is out of phase with $\mathrm{CH}_{4}$ production and might occur during periods when peat temperatures are below the ideal for methanogenesis, such as periods that are infrequently studied. This suggests a seasonal pattern for $\mathrm{CH}_{4}$ cycling where AOM functions as a significant $\mathrm{CH}_{4}$ sink by consuming $\mathrm{CH}_{4}$ when methanogenesis rates are small. Alternatively, AOM could proceed during cold periods when the wetland surface is frozen, diffusion transport and ebullition are limited, and $\mathrm{CH}_{4}$ accumulates.

Furthermore, AOM assays conducted using peat from a suite of sites (Smemo and Yavitt, 2007) demonstrated that AOM occurs in a variety of peatlands ranging from nutrient-poor (ombrotrophic) bogs to nutrient-rich (minerotrophic) fens. Because they found AOM was quantitatively more important in minerotrophic systems with groundwater and surface water inputs, it seemed possible

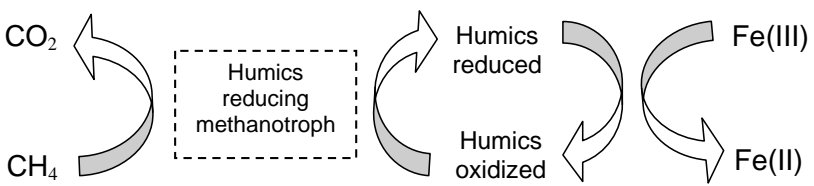

Fig. 4. Conceptual mechanism for $\mathrm{CH}_{4}$ oxidation linked to humic substance mediated Fe(III) reduction. Adapted from Scott et al. (1998).

that potential electron acceptors for the process were supplied by hydrologic inputs. Temporal patterns in a nutrientrich fen showed seasonal and annual water table height and redox status patterns, and the authors suggested that such patterns could drive re-oxidation of reduced compounds and therefore represent an electron acceptor replenishment mechanism necessary to maintain AOM.

\section{Global $\mathrm{CH}_{4}$ cycle}

AOM appears to be a potential sink for $\mathrm{CH}_{4}$ production in some peatland ecosystems and therefore a constraint on $\mathrm{CH}_{4}$ fluxes to the atmosphere. Nevertheless, it is unclear whether the process is quantitatively important at the ecosystem or global scale, or simply a novel process that occurs but consumes less than the annual variation in global $\mathrm{CH}_{4}$ fluxes. Smemo and Yavitt (2006) reported circumstantial evidence that suggested AOM might be a significant constraint on $\mathrm{CH}_{4}$ fluxes during very wet years in a peatland in Central New York State. Fluxes were much less than expected given redox conditions and porewater $\mathrm{CH}_{4}$ concentrations. Smemo and Yavitt (2007) also reported net AOM rates in the same peatland up to $176 \mathrm{nmol} \mathrm{kg}$ peat ${ }^{-1} \mathrm{~s}^{-1}$, with mean a mean rate of $17 \mathrm{nmol} \mathrm{kg}^{-1} \mathrm{~s}^{-1}$. Using an AOM rate of $10 \mathrm{nmol} \mathrm{kg}^{-1} \mathrm{~s}^{-1}$ with $\sim 3$ months of activity per year, each $\mathrm{kg}$ of dry peat could oxidize 1-2 grams of $\mathrm{CH}_{4}$ annually. This represents about $50 \%$ of $\mathrm{CH}_{4}$ efflux into the atmosphere. With the exception of experiments using methanogenic inhibitors, Smemo and Yavitt (2007) presented net oxidation rates that potentially underestimate gross $\mathrm{CH}_{4}$ oxidation rates, and the rates from this study were similar to many published rates of $\mathrm{CH}_{4}$ production and aerobic $\mathrm{CH}_{4}$ oxidation (e.g. Moore and Dalva, 1997). AOM might then function to stabilize peatland $\mathrm{CH}_{4}$ fluxes. In contrast, AOM could be sensitive to initial conditions and thermodynamically constrained in natural environments, thus not quantifiably important in terms of annual $\mathrm{CH}_{4}$ budgets.

Scaling process rates to annual global fluxes is tricky business because published peatland AOM rates are few and insitu measurements are lacking. Laboratory assays often fail to reflect the actual conditions of the study environment and tend to select for organisms that may not be ecologically significant (Liesack et al., 2000). Nevertheless, we can make rough estimates using the AOM rates reported by Smemo 
and Yavitt (2007). Although the rates reported in this study are low with respect microbial metabolic rates, they are 45 orders of magnitude higher than in marine sediments and anoxic waters. This disparity is realistic because Bacteria and Archaea in many marine sediments have slow metabolic rates due to low temperatures and small inputs of organic $\mathrm{C}$ to drive metabolism. Reported rates of AOM tied to denitrification in agricultural canals (Raghoebarsing et al., 2006) were also lower than this estimate, but these estimates were from inoculated sequencing batch reactors where $\mathrm{CH}_{4}$ was the primary $\mathrm{C}$ source. This is not the case in most wetland soils where organic $\mathrm{C}$ sources are plentiful. If we assume a modest AOM rate of $5 \mathrm{nmol} \mathrm{kg}^{-1} \mathrm{~s}^{-1}$ as an average for peatlands between 50 and $70^{\circ} \mathrm{N}$ (area $=2.65 \times 10^{12} \mathrm{~m}^{2}$ (Matthews and Fung, 1987)), a peat bulk density of $0.1 \mathrm{~g} \mathrm{~cm}^{-3}$, and 3 months of AOM activity each year in $50 \%$ of the top $50 \mathrm{~cm}$ of peat, northern peatlands could anaerobically consume $41 \mathrm{Tg}$ of $\mathrm{CH}_{4}$ on average each year. This is roughly equal to $\mathrm{CH}_{4}$ flux estimates for northern peatlands of $\sim 38 \mathrm{Tg}$ (Bartlett and Harriss, 1993). In other words, enhanced aerobic $\mathrm{CH}_{4}$ oxidation rates notwithstanding, northern peatland $\mathrm{CH}_{4}$ emission rates could be $2 \mathrm{x}$ the current rate in the absence of AOM. Better studies to confirm this hypothesis are certainly needed given the inherent temporal and spatial variability of microbial processes in peatlands, but such estimates imply that the process can be globally significant and deserves further attention.

\section{Challenges and future directions}

Considering the massive $\mathrm{CO}_{2}$ sink and significant $\mathrm{CH}_{4}$ source that peatlands represent and their sensitivity to environmental changes (Gorham, 1991), it behooves us to better understand the patterns and processes that control $\mathrm{C}$ cycling in these systems. New evidence suggests that AOM may be one of these processes, yet despite current findings (Smemo and Yavitt, 2007) we still know little about the process and the organisms involved and many challenges remain (Caldwell et al., 2008). Compared to deep marine sediments that are more or less constant in regards to temperature, chemistry, $\mathrm{pH}$, and organic $\mathrm{C}$ inputs, peat soils represent a complex matrix in which to study the processes and mechanisms controlling $\mathrm{C}$ cycling. Wetlands in general are highly heterogeneous environments that experience temperature, $\mathrm{pH}$, hydrologic, chemistry and redox fluctuations at a variety of scales. Moreover, the presence of plant roots further increases redox, nutrient and $\mathrm{C}$ substrate gradients. This heterogeneity directly and indirectly influences factors controlling AOM. Studying specific processes in peat is consequently a daunting task, and new techniques and methods are needed to address questions pertaining to electron acceptors, pathways, and ecosystem importance.
A first logical step towards achieving these goals is to focus effort on obtaining in situ AOM measurements in peatlands, and then generating and testing new hypotheses relating to mechanisms. Laboratory methods are useful as they provide a controlled environment for constraining variability, selecting for particular processes, identifying novel processes, and asking basic mechanistic questions. Laboratory studies are, however, inherently limited when one attempts to quantify the importance of the process in nature (Liesack et al., 2000). In short, potential activity does not necessarily equate with function, particularly with respect to systems such as peatlands that are biogeochemically complex across space and time. New field-based techniques, such as those involving isotopic tracers or specific inhibitors, are clearly needed. We also should further facilitate the use of modern molecular techniques that have expanded our knowledge of AOM in marine (e.g. Boetius et al., 2000; Orphan et al., 2001; Pancost et al., 2000; Thomsen et al., 2001) and freshwater systems (e.g. Raghoebarsing et al., 2006; Ettwig et al., 2010, 2008). Although we have focused on AOM in peatland ecosystems, AOM may be broadly important across wetland type and location. In fact, if AOM in freshwater systems is related to Fe or S cycling, then AOM should be evaluated in non peat-forming wetlands where organic matter turnover is fast and $\mathrm{CH}_{4}$ fluxes are high, such as those in the tropics (Bartlett and Harriss, 1993).

Acknowledgements. We would like to thank all of those who provided comments on earlier drafts of this manuscript, including Stephen H. Zinder, Timothy J. Fahey, Peter M. Groffman, and Wendy M. Mahaney. Their insight and comments led to considerable improvements. We would also like to thank Andria Blackwood for help with graphics in the conceptual figure. Funding for this work was provided by the US National Science Foundation and US Department of Agriculture.

Edited by: K. Küsel

\section{References}

Alewell, C., Paul, S., Lischeid, G., and Storck, F. R.: Co-regulation of redox processes in freshwater wetlands as a function of organic matter availability?, Sci. Total Environ., 404, 335-342, 2008.

Alperin, M. and Hoehler, T.: The Ongoing Mystery of Sea-Floor Methane, Science, 329, 288-289, 2010.

Alperin, M. J. and Reeburgh, W. S.: Geochemical evidence supporting anaerobic methane oxidation, in: Microbial Growth on C1 Compounds, American Society for Microbiology, Washington D.C., 282-289, 1984.

Alperin, M. J. and Reeburgh, W. S.: Inhibition experiments on anaerobic methane oxidation, Appl. Environ. Microbiol., 50, 940-945, 1985.

Barnes, R. O. and Goldberg, E. D.: Methane production and consumption in anaerobic marine sediments, Geology, 4, 297-300, 1976. 
Bartlett, K. and Harriss, R.: Review and assessment of methane emissions from wetlands, Chemosphere, 26, 261-320, 1993.

Bauer, M., Heitmann, T., Macalady, D. L., and Blodau, C.: Electron transfer capacities and reaction kinetics of peat dissolved organic matter, Environ. Sci. Technol., 41, 139-145, 2007.

Beal, E. J., House, C. H., and Orphan, V. J.: Manganese- and IronDependent Marine Methane Oxidation, Science, 325, 184-187, 2009.

Beal, E. J., Claire, M. W., and House, C. H.: High rates of anaerobic methanotrophy at low sulfate concentrations with implications for past and present methane levels, Geobiology, 9, 131-139, doi:10.1111/j.1472-4669.2010.00267.x, 2011.

Beer, J. and Blodau, C.: Transport and thermodynamics constrain belowground carbon turnover in a northern peatland, Geochim. Cosmochim. Ac., 71, 2989-3002, 2007.

Bellisario, L. M., Bubier, J. L., and Moore, T. R.: Controls on $\mathrm{CH}_{4}$ emissions from a northern peatland, Global Biogeochem. Cy., 13, 81-91, 1999.

Billett, M. F. and Moore, T. R.: Supersaturation and evasion of $\mathrm{CO}_{2}$ and $\mathrm{CH}_{4}$ in surface waters at Mer Bleue peatland, Canada, Hydrol. Process., 22, 2044-2054, 2008.

Bjerg, P. L., Rüegge, K., Pedersen, J. K., and Christensen, T. H.: Distribution of redox-sensitive groundwater quality parameters down gradient of a landfill (Grindsted, Denmark), Environ. Sci. Technol., 28, 1387-1394, 1995.

Blodau, C., Mayer, B., Peiffer, S., and Moore, T. R.: Support for an anaerobic sulfur cycle in two Canadian peatland soils, J. Geophys. Res.-Biogeosci., 112, G02004, doi:10.1029/2006JG000364, 2007a.

Blodau, C., Roulet, N. T., Heitmann, T., Stewart, H., Beer, J., Lafleur, P., and Moore, T. R.: Belowground carbon turnover in a temperate ombrotrophic bog, Global Biogeochem. Cy., 21, Gb1021, doi:10.1029/2005GB002659, 2007b.

Boetius, A., Ravenschlag, K., Schubert, C. J., Rickert, D., Widdel, F., Gieseke, A., Amann, R., Jorgensen, B. B., Witte, U., and Pfannkuche, O.: A marine microbial consortium apparently mediating anaerobic oxidation of methane, Nature, 407, 623-626, doi:10.1038/35036572, 2000.

Bosse, U., Frenzel, P., and Conrad, R.: Inhibition of methane oxidation by ammonium in the surface layer of a littoral sediment, FEMS Microbiol. Ecol., 13, 123-134, 1993.

Bubier, J. L.: The relationship of vegetation to methane emission and hydrochemical gradients in northern peatlands, J. Ecol., 83, 403-420, 1995.

Bubier, J. L., Moore, T. R., Bellisario, L., and Comer, N. T.: Ecological controls on methane emissions from a northern peatland complex in the zone of discontinuous permafrost, Manitoba, Canada, Global Biogeochem. Cy., 9, 455-470, 1995a.

Bubier, J. L., Moore, T. R., and Juggins, S.: Predicting methane emission from bryophyte distribution in northern Canadian peatlands, Ecology, 76, 677-693, 1995b.

Cadillo-Quiroz, H., Yashiro, E., Yavitt, J. B., and Zinder, S. H.: Characterization of the archaeal community in a minerotrophic fen and terminal restriction fragment length polymorphismdirected isolation of a novel hydrogenotrophic methanogen, Appl. Environ. Microbiol., 74, 2059-2068, 2008.

Caldwell, S. L., Laidler, J. R., Brewer, E. A., Eberly, J. O., Sandborgh, S. C., and Colwell, F. S.: Anaerobic oxidation of methane: mechanisms, bioenergetics, and the ecology of associated mi- croorganisms, Environ. Sci. Technol., 42, 6791-6799, 2008.

Capone, D. G. and Knapp, A. N.: A marine nitrogen cycle fix?, Nature, 445, 159-160, 2007.

Catling, D. C., Claire, M. W., and Zahnle, K. J.: Anaerobic methanotrophy and the rise of atmospheric oxygen, Philos. Trans. R. Soc. A., 365, 1867-1888, 2007.

Crowe, S. A., Katsev, S., Leslie, K., Sturm, A., Magen, C., Nomosatryo, S., Pack, M. A., Kessler, J. D., Reeburgh, W. S., Roberts, J. A., GonzÁLez, L., Douglas Haffner, G., Mucci, A., Sundby, B., and Fowle, D. A.: The methane cycle in ferruginous Lake Matano, Geobiology, 9, 61-78, doi:10.1111/j.14724669.2010.00257.x, 2011

Dalsgaard, T. and Thamdrup, B.: Factors controlling anaerobic ammonium oxidation with nitrite in marine sediments, Appl. Environ. Microbiol., 68, 3802-3808, 2002.

Dalsgaard, T., Canfield, D. E., Petersen, J., Thamdrup, B., and Acuña-Gonzalez, $\mathrm{J} .: \mathrm{N}_{2}$ production by the ANAMMOX reaction in the anoxic water column of Golfo Dulce, Costa Rica, Nature, 422, 606-608, 2003.

Damman, A. W. H.: Distribution and movement of elements in ombrotrophic peat bogs, OIKOS, 30, 480-495, 1978.

Daniel, R., Warnecke, F., Potekhina, J. S., and Gottschalk, G.: Identification of the syntrophic partners in a coculture coupling anaerobic methanol oxidation to Fe(III) reduction, FEMS Microbiol. Lett., 180, 197-203, 1999.

Deppe, M., McKnight, D. M., and Blodau, C.: Effects of short-term drying and irrigation on electron flow in mesocosms of a northern bog and an alpine fen, Environ. Sci. Technol., 44, 80-86, 2010.

Dettling, M. D., Yavitt, J. B., and Zinder, S. H.: Control of organic carbon mineralization by alternative electron acceptors in four peatlands, Central New York State, USA, Wetlands, 26, 917927, 2006.

Dettling, M. D., Yavitt, J. B., Cadillo-Quiroz, H., Sun, C., and Zinder, S. H.: Soil-methanogen interactions in two peatlands (bog, fen) in Central New York State, Geomicrobiol. J., 24, 247-259, 2007.

Devol, A. H.: Solution to a marine mystery, Nature, 422, 575-576, 2003.

Dise, N. B.: Methane emissions from Minnesota peatlands: spatial and seasonal variability, Global Biogeochem. Cy., 7, 123-142, 1993.

Dise, N. B. and Verry, E. S.: Suppression of peatland methane emission by cumulative sulfate deposition in simulated acid rain, Biogeochemistry, 53, 143-160, 2001.

Eller, G., Kanel, L. K., and Kruger, M.: Cooccurrence of aerobic and anaerobic methane oxidation in the water column of Lake Plußsee, Appl. Environ. Microbiol., 71, 8925-8928, 2005.

Eriksson, T., Öquist, M. G., and Nilsson, M. B.: Production and oxidation of methane in a boreal mire after a decade of increased temperature and nitrogen and sulfur deposition, Glob. Change Biol., 16, 2130-2144, 2010.

Ettwig, K. F., Shima, S., van de Pas-Schoonen, K. T., Kahnt, J., Medema, M. H., op den Camp, H. J. M., Jetten, M. S. M., and Strous, M.: Denitrifying bacteria anaerobically oxidize methane in the absence of Archaea, Environ. Microbiol., 10, 3164-3173, 2008.

Ettwig, K. F., van Alen, T., van de Pas-Schoonen, K. T., Jetten, M. S. M., and Strous, M.: Enrichment and molecular detection of denitrifying methanotrophic bacteria of the NC10 Phylum, Appl. 
Environ. Microbiol., 75, 3656-3662, 2009.

Ettwig, K. F., Butler, M. K., Le Paslier, D., Pelletier, E., Mangenot, S., Kuypers, M. M. M., Schreiber, F., Dutilh, B. E., Zedelius, J., de Beer, D., Gloerich, J., Wessels, H., van Alen, T., Luesken, F., Wu, M. L., van de Pas-Schoonen, K. T., den Camp, H., JanssenMegens, E. M., Francoijs, K. J., Stunnenberg, H., Weissenbach, J., Jetten, M. S. M., and Strous, M.: Nitrite-driven anaerobic methane oxidation by oxygenic bacteria, Nature, 464, 543-548, 2010.

Frenzel, P., Bosse, U., and Janssen, P. H.: Rice roots and methanogenesis in a paddy soil: ferric iron as an alternative electron acceptor in the rooted soil, Soil Biol Biochem, 31, 421-430, 1999.

Frolking, S. and Crill, P.: Climate control on temporal variability of methane flux from a poor fen in southeastern New Hampshire: measurement and modeling, Global Biogeochem. Cy., 8, 385397, 1994.

Gauci, V., Dise, N., and Blake, S.: Long-term suppression of wetland methane flux following a pulse of simulated acid rain, Geophys. Res. Lett., 32, L12804, doi:10.1029/2005GL022544, 2005.

Gorham, E., Eisenreich, S. J., Ford, J., and Santelmann, M. V.: The chemistry of bog waters, in: Chemical processes in lakes, John Wiley \& Sons, Hoboken, NJ, 339-363, 1985.

Gorham, E.: Northern peatlands: role in the carbon cycle and probable responses to climatic warming, Ecol. Appl., 1, 182-195, 1991.

Grossman, E. L., Cifuentes, L. A., and Cozzarelli, I. M.: Anaerobic methane oxidation in a landfill leachate plume, Environ. Sci. Technol., 36, 2436-2442, 2002.

Hallam, S. J., Putnam, N., Preston, C. M., Detter, J. C., Rokhsar, D. S., Richardson, P. M., and DeLong, E. F.: Reverse methanogenesis: testing the hypothesis with environmental genomics, Science, 305, 1457-1462, 2004.

Heitmann, T. and Blodau, C.: Oxidation and incorporation of hydrogen sulfide by dissolved organic matter, Chem. Geol., 235, 12-20, 2006.

Heitmann, T., Goldhammer, T., Beer, J., and Blodau, C.: Electron transfer of dissolved organic matter and its potential significance for anaerobic respiration in a northern bog, Glob. Change Biol., 13, 1771-1785, 2007.

Hinrichs, K.-U. and Boetius, A.: The anaerobic oxidation of methane: new insights in microbial ecology and biogeochemistry, in: Ocean Margin Systems, Springer Verlag, Heidelberg, 2002.

Hinrichs, K., Hayes, J. M., Sylva, S. P., Brewer, P. G., and DeLong, E. F.: Methane-consuming archaebacteria in marine sediments, Nature, 398, 802-805, 1999.

Hoehler, T. M., Alperin, M. J., Albert, D. B., and Martens, C. S.: Field and laboratory studies of methane oxidation in an anoxic marine sediment-evidence for a methanogen-sulfate reducer consortium, Global Biogeochem. Cy., 8, 451-463, 1994.

Hornibrook, E. R. C., Bowes, H. L., Culbert, A., and GallegoSala, A. V.: Methanotrophy potential versus methane supply by pore water diffusion in peatlands, Biogeosciences, 6, 1491-1504, doi:10.5194/bg-6-1491-2009, 2009.

IPCC: Climate Change 2007: The Physical Science Basis. Contribution of Working Group I to the Fourth Assessment Report of the Intergovernmental Panel on Climate Change, Cambridge University Press, Cambridge, United Kingdom, 2007.

Islas-Lima, S., Thalasso, F., and Gómez-Hernandez, J.: Evidence of anoxic methane oxidation coupled to denitrification, Water Res., 38, 13-16, 2004.

Iversen, N., Oremland, R. S., and Klug, M. J.: Big Soda Lake (Nevada). 3. Pelagic methanogenesis and anaerobic methane oxidation, Limnol. Oceanogr., 32, 804-814, 1987.

Jäckel, U. and Schnell, S.: Suppression of methane emission from rice paddies by ferric iron fertilization, Soil Biology and Biochemistry, 32, 1811-1814, 2000.

Jetten, M. S. M., Strous, M., van de Pas-Schoonen, K. T., Schalk, J., van Dongen, U. G. J. M., van de Graaf, A. A., Logemann, S., Muyzer, G., van Loosdrecht, M. C. M., and Kuenen, J. G.: The anaerobic oxidation of ammonium, FEMS Microbiol. Rev., 22, 421-437, 1999.

Kappler, A., Benz, M., Schink, B., and Brune, A.: Electron shuttling via humic acids in microbial iron(III) reduction in a freshwater sediment, FEMS Microbiol. Ecol., 47, 85-92, 2004.

Keller, J. K. and Bridgham, S. D.: Pathways of anaerobic carbon cycling across an ombrotrophic-minerotrophic peatland gradient, Limnol. Oceanogr., 52, 96-107, 2007.

Kluber, H. D. and Conrad, R.: Effects of nitrate, nitrite, NO and $\mathrm{N}_{2} \mathrm{O}$ on methanogenesis and other redox processes in anoxic rice field soil, FEMS Microbiol. Ecol., 25, 301-318, 1998.

Knittel, K. and Boetius, A.: Anaerobic Oxidation of Methane: progress with an Unknown Process, Annu. Rev. Microbiol., 63, 311-334, 2009.

Knorr, K. H. and Blodau, C.: Impact of experimental drought and rewetting on redox transformations and methanogenesis in mesocosms of a northern fen soil, Soil Biol. Biochem., 41, 11871198, 2009.

Knorr, K. H., Lischeid, G., and Blodau, C.: Dynamics of redox processes in a minerotrophic fen exposed to a water table manipulation, Geoderma, 153, 379-392, 2009.

Küsel, K., Blöthe, M., Schulz, D., Reiche, M., and Drake, H. L.: Microbial reduction of iron and porewater biogeochemistry in acidic peatlands, Biogeosciences, 5, 1537-1549, doi:10.5194/bg-5-1537-2008, 2008.

Kuypers, M. M. M., Sliekers, A. O., Lavik, G., Schmid, M., Jorgensen, B. B., Kuenen, J. G., Damste, J. S. S., Strous, M., and Jetten, M. S. M.: Anaerobic ammonium oxidation by anammox bacteria in the Black Sea, Nature, 422, 608-611, 2003.

Liesack, W., Schnell, S., and Revsbech, N. P.: Microbiology of flooded rice paddies, FEMS Microbiol. Rev., 24, 625-645, 2000.

Limpens, J., Berendse, F., Blodau, C., Canadell, J. G., Freeman, C., Holden, J., Roulet, N., Rydin, H., and Schaepman-Strub, G.: Peatlands and the carbon cycle: from local processes to global implications - a synthesis, Biogeosciences, 5, 1475-1491, doi:10.5194/bg-5-1475-2008, 2008.

Lovley, D. R. and Phillips, E. J. P.: Organic matter mineralization with reduction of ferric iron in anaerobic sediments, Appl. Environ. Microbiol., 51, 683-689, 1986.

Lovley, D. R. and Phillips, E. J. P.: Novel mode of microbial energy metabolism: organic carbon oxidation coupled to dissimilatory reduction of iron or manganese, Appl. Environ. Microbiol., 54, 1472-1480, 1988

Lovley, D. R., Coates, J. D., Blunt, H. E. L., Phillips, E. J. P., and Woodward, J. C.: Humic substances as electron acceptors for microbial respiration, Nature, 382, 445-448, 1996.

Loy, A., Küsel, K., Lehner, A., Drake, H. L., and Wagner, M.: Microarray and functional gene analyses of sulfate-reducing 
prokaryotes in low-sulfate, acidic fens reveal cooccurrence of recognized genera and novel lineages, Appl. Environ. Microbiol., 70, 6998-7009, 2004.

Malek, R. E. and Weismann, T. J.: Cyclic behavior in anaerobic methane production and oxidation, J. Penn. Acad. Sci., 62, 155159, 1988.

Matthews, E. and Fung, I.: Methane emission from natural wetlands: global distribution, area, and environmental characteristics of sources, Global Biogeochem. Cy., 1, 61-86, 1987.

Michaelis, W., Seifert, R., Nauhaus, K., Treude, T., Thiel, V., Blumenberg, M., Knittel, K., Gieseke, A., Peterknecht, K., Pape, T., Boetius, A., Amann, R., Jørgensen, B. B., Widdel, F., Peckmann, J., Pimenov, N. V., and Gulin, M. B.: Microbial reefs in the Black Sea fueled by anaerobic oxidation of methane, Science, 297, 1013-1015, 2002.

Mikaloff Fletcher, S. E., Tans, P. P., Bruhwiler, L. M., Miller, J. B., and Heimann, M.: $\mathrm{CH}_{4}$ sources estimated from atmospheric observations of $\mathrm{CH}_{4}$ and its $\mathrm{C}-13 / \mathrm{C}-12$ isotopic ratios: 1 . Inverse modeling of source processes, Global Biogeochem. Cy., 18, Gb4004, doi:10.1029/2004GB002223, 2004.

Mikkela, C., Sundh, I., Svensson, B. H., and Nilsson, M.: Diurnal variation in methane emission in relation to the water table, soil temperature, climate and vegetation cover in a Swedish acid mire, Biogeochemistry, 28, 93-114, 1995.

Miletto, M., Loy, A., Antheunisse, A. M., Loeb, R., Bodelier, P. L. E., and Laanbroek, H. J.: Biogeography of sulfate-reducing prokaryotes in river floodplains, FEMS Microbiol. Ecol., 64, 395-406, 2008.

Miller, D. N., Ghiorse, W. C., and Zinder, S. H.: High purity ${ }^{14} \mathrm{CH}_{4}$ generation using the thermophilic acetotrophic methanogen Methanothrix sp. strain CALS-1, J. Microbiol. Meth., 35, 151156, 1999.

Miura, Y., Watnabe, A., Murase, J., and Kimura, M.: Methane production and its fate in paddy fields, Soil Sci. Plant Nutr., 38, 673679, 1992.

Moore, T. R. and Knowles, R.: The influence of water table levels on methane and carbon dioxide emissions from peatland soils, Can. J. Soil Sci., 69, 33-38, 1989.

Moore, T. R. and Dalva, M.: Methane and carbon dioxide exchange potentials of peat soils in aerobic and anaerobic laboratory incubations, Soil Biol, Biochem, 29, 1157-1164, 1997.

Murase, J. and Kimura, M.: Methane production and its fate in paddy fields: VI. Anaerobic oxidation of methane in plow layer soil, Soil Sci. Plant Nutr., 40, 505-514, 1994a.

Murase, J. and Kimura, M.: Methane production and its fate in patty fields: IV. Sources of microorganisms and substrates responsible for anaerobic methane oxidation, Soil Sci. Plant Nutr., 40, 57-61, 1994b.

Murase, J. and Kimura, M.: Methane production and its fate in paddy fields: VII. Electron acceptors responsible for anaerobic methane oxidation, Soil Sci. Plant Nutr., 40, 647-654, 1994c.

Nauhaus, K., Albrecht, M., Elvert, M., Boetius, A., and Widdel, F.: In vitro cell growth of marine archaeal-bacterial consortia during anaerobic oxidation of methane with sulfate, Environ. Microbiol., 9, 187-196, 2007.

Nedwell, D. B. and Watson, A.: $\mathrm{CH}_{4}$ production, oxidation and emission in a U.K. ombrotrophic peat bog: Influence of $\mathrm{SO}_{4}^{2-}$ from acid rain, Soil Biol. Biochem., 27, 893-903, 1995.

Niemann, H., Hitz, C., Blees, J., Schubert, C. J., Veronesi, M., Si- mona, M., and Lehmann, M. F.: Biogeochemical signatures of the anaerobic methane oxidation in a south alpine lake (Lake Lugano), Geochim. Cosmochim. Acta, 73, A942-A942, 2009.

Nilsson, M., Sagerfors, J., Buffam, I., Laudon, H., Eriksson, T., Grelle, A., Klemedtsson, L., Weslien, P., and Lindroth, A.: Contemporary carbon accumulation in a boreal oligotrophic minerogenic mire - a significant sink after accounting for all $\mathrm{C}$ fluxes, Glob. Change Biol., 14, 2317-2332, 2008.

Nozhevnikova, A. N., Zepp, K., Vazquez, F., Zehnder, A. J. B., and Holliger, C.: Evidence for the existence of psychrophilic methanogenic communities in anoxic sediments of deep lakes, Appl. Environ. Microbiol., 69, 1832-1835, 2003.

Oremland, R. S.: NO connection with methane, Nature, 464, 500501, 2010.

Orphan, V. J., House, C. H., Hinrichs, K.-U., McKeegan, K. D., and Delong, E. F.: Methane-consuming archaea revealed by directly coupled isotopic and phylogenetic analysis, Science, 293, 484487, 2001.

Orphan, V. J., House, C. H., Hinrichs, K-U., McKeegan, K. D., and DeLong, E. F.: Multiple microbial groups mediate methane oxidation in anoxic marine sediments, Proc. Nat. Acad. Sci., 99, 7663-7668, 2002.

Pancost, R. D., Sinninghe Damsté, J. S., de Lint, S., van der Maarel, M. J. E. C., and Gottschal, J. C.: Biomarker evidence for widespread anaerobic methane oxidation in Mediterranean sediments by a consortium of methanogenic archaea and bacteria., Appl. Environ. Microbiol., 66, 1126-1132, 2000.

Panganiban, A. T. J., Patt, T. E., Hart, W., and Hanson, R. S.: Oxidation of methane in the absence of oxygen in lake water samples, Appl. Environ. Microbiol., 37, 303-309, 1979.

Prietzel, J., Thieme, J., Tyufekchieva, N., Paterson, D., McNulty, I., and Kogel-Knabner, I.: Sulfur speciation in well-aerated and wetland soils in a forested catchment assessed by sulfur K-edge X-ray absorption near-edge spectroscopy (XANES), J. Plant Nutr. Soil Sc., 172, 393-403, 2009.

Raghoebarsing, A. A., Pol, A., van de Pas-Schoonen, K. T., Smolders, A. J. P., Ettwig, K. F., Rijpstra, W. I. C., Schouten, S., Sinninghe Damsté, J. S., Op den Camp, H. J. M., Jetten, M. S. M., and Strous, M.: A microbial consortium couples anaerobic methane oxidation to denitrification, Nature, 440, 918-921, 2006.

Reeburgh, W. C.: Methane consumption in Carioca Trench waters and sediments, Earth Planet. Sc. Lett., 28, 337-344, 1976.

Reeburgh, W. S. and Heggie, D. T.: Microbial methane consumption reactions and their effect on methane distributions in freshwater and marine environments, Limnol. Oceanogr., 22, 1-9, 1977.

Reeburgh, W. S.: Coupling of the carbon and sulfur cycles through anaerobic methane oxidation, in: Evolution of the global biogeochemical sulfur cycle, Wiley, New York, 149-159, 1989.

Reeburgh, W. S.: Oceanic methane biogeochemistry, Chem. Rev., 107, 486-513, 2007.

Reiche, M., Torburg, G., and Küsel, K.: Competition of Fe(III) reduction and methanogenesis in an acidic fen, FEMS Microbiol. Ecol., 65, 88-101, 2008.

Roden, E. E. and Wetzel, R. G.: Organic carbon oxidation and suppression of methane production by microbial Fe(III) oxide reduction in vegetated and unvegetated freshwater wetland sediments, Limnol. Oceanogr., 41, 1733-1748, 1996. 
Roy, R. and Conrad, R.: Effect of methanogenic precursors (acetate, hydrogen, propionate) on the suppression of methane production by nitrate in anoxic rice field soil, FEMS Microbiol. Ecol., 28, 49-61, 1999.

Scheller, S. M. G., Boecher, R., Thauer, R. K., and Jaun, B.: The key nickel enzyme of methanogenesis catalyses the anaerobic oxidation of methane, Nature, 465, 606-609, 2010.

Schink, B.: Energetics of syntrophic cooperation in methanogenic degradation, Microbiol. Mol. Biol. R., 61, 262-280, 1997.

Schmalenberger, A., Drake, H. L., and Küsel, K.: High unique diversity of sulfate-reducing prokaryotes characterized in a depth gradient in an acidic fen, Environ. Microbiol., 9, 1317-1328, 2007.

Scholten, J. C. M., van Bodegom, P. M., Vogelaar, J., van Ittersum, A., Hordijk, K., Roelofsen, W., and Stams, A. J. M.: Effect of sulfate and nitrate on acetate conversion by anaerobic microorganisms in a freshwater sediment, FEMS Microbiol. Ecol., 42, 375-385, 2002.

Scholten, J. C. M., Joye, S. B., Hollibaugh, J. T., and Murrell, J. C.: Molecular analysis of the sulfate reducing and archaeal community in a meromictic soda lake (Mono Lake, California) by targeting 16S rRNA, mcrA, apsA, and dsrAB genes, Microb. Ecol., 50, 29-39, 2005.

Schönheit, P., Kristjansson, J. K., and Thauer, R. K.: Kinetic mechanism for the ability of sulfate reducers to out-compete methanogens for acetate, Archiv. Microbiol., 132, 285-288, 1982.

Schubert, C. J., Lucas, F. S., Durisch-Kaiser, E., Stierli, R., Diem, T., Scheidegger, O., Vazquez, F., and Müller, B.: Oxidation and emission of methane in a monomictic lake (Rotsee, Switzerland), Aquat. Sci., 72, 455-466, doi:10.1007/s00027-010-0148$5,2010$.

Scott, D. T., McKnight, D. M., Blunt, H. E. L., Lovley, D. R., and Kolesar, S. E.: Quinone groups in humic substances as electron acceptors by humic-reducing microorganisms, Environ. Sci. Technol., 32, 2984-2989, 1998.

Segers, R.: Methane production and methane consumption: a review of processes underlying wetland methane fluxes, Biogeochemistry, 41, 23-51, 1998.

Smemo, K. A.: Methane cycling in northern peatland ecosystems: A potential role for anaerobic methane oxidation, Ph.D. thesis, Cornell University, Ithaca, NY, USA, 138 pp., 2003.

Smemo, K. A. and Yavitt, J. B.: A multi-year perspective on methane cycling in a shallow peat fen in Central New York State, USA, Wetlands, 26, 20-29, 2006.

Smemo, K. A. and Yavitt, J. B.: Evidence for anaerobic $\mathrm{CH}_{4}$ oxidation in freshwater peatlands, Geomicrobiol. J., 24, 583-597, 2007.

Smith, R. L., Howes, B. L., and Garabedian, S. P.: In situ measurement of methane oxidation in groundwater by using naturalgradient tracer tests, Appl. Environ. Microbiol., 57, 1997-2004, 1991.

Smith, R. L., Miller, L. G., and Howes, B. L.: The geochemistry of methane in Lake Fryxell, an amictic, permanently ice-covered, Antarctic lake, Biogeochemistry, 21, 95-115, 1993.

Sørensen, J.: Dimethylsulfide and methane thiol in sediment porewater of a Danish estuary, Biogeochemistry, 6, 201-210, 1988.

Sørensen, K. B., Finster, K., and Ramsing, N. B.: Thermodynamic and kinetic requirements in anaerobic methane oxidizing consor- tia exclude hydrogen, acetate, and methanol as possible electron shuttles, Microb. Ecol., 42, 1-10, 2001.

Steinmann, P., and Shotyk, W.: Geochemistry, mineralogy, and geochemical mass balance on major elements in two peat bog profiles (Jura Mountains: Switzerland), Chem. Geol., 138, 25-53, 1997a.

Steinmann, P. and Shotyk, W.: Chemical composition, pH, and redox state of sulfur and iron in complete vertical porewater profiles from two Sphagnum peat bogs, Jura Mountains, Switzerland, Geochim. Cosmochim. Acta, 61, 1143-1163, $1997 \mathrm{~b}$.

Strous, M., Pelletier, E., Mangenot, S., Rattei, T., Lehner, A., Taylor, M. W., Horn, M., Daims, H., Bartol-Mavel, D., Wincker, P., Barbe, V., Fonknechten, N., Vallenet, D., Segurens, B., Schenowitz-Truong, C., Medigue, C., Collingro, A., Snel, B., Dutilh, B. E., Op den Camp, H. J. M., van der Drift, C., Cirpus, I., van de Pas-Schoonen, K. T., Harhangi, H. R., van Niftrik, L., Schmid, M., Keltjens, J., van de Vossenberg, J., Kartal, B., Meier, H., Frishman, D., Huynen, M. A., Mewes, H. W., Weissenbach, J., Jetten, M. S. M., Wagner, M., and Le Paslier, D.: Deciphering the evolution and metabolism of an anammox bacterium from a community genome, Nature, 440, 790-794, 2006.

Stubner, S., Wind, T., and Conrad, R.: Sulfur oxidation in rice field soil: Activity, enumeration, isolation and characterization of thiosulfate-oxidizing bacteria, Syst. Appl. Microbiol., 21, 569578, 1998.

Sundh, I., Mikkela, C., Nilsson, M., and Svensson, B. H.: Potential aerobic methane oxidation in a sphagnum-dominated peatland: controlling factors and relation to methane emission, Soil Biol. and Biochem., 27, 829-837, 1995.

Thauer, R. K. and Shima, S.: Methane and microbes, Nature, 440, 878-879, 2006.

Thauer, R. K. and Shima, S.: Methane as fuel for anaerobic microorganisms, in: Incredible Anaerobes: From Physiology to Genomics to Fuels, Annals of the New York Academy of Sciences, 158-170, 2008.

Thomsen, T. R., Finster, K., and Ramsing, N. B.: Biogeochemical and molecular signatures of anaerobic methane oxidation in a marine sediment, Appl. Environ. Microbiol., 67, 1646-1656, 2001.

Topp, E. and Pattey, E.: Soils as sources and sinks for atmospheric methane, Can. J. Soil Sci., 77, 167-178, 1997.

Turunen, J., Tomppo, E., Tolonen, K., and Reinikainen, A.: Estimating carbon accumulation rates of undrained mires in Finlandapplication to boreal and subarctic regions, Holocene, 12, 69-80, 2002.

Updegraff, K., Bridgham, S. D., Pastor, J., Weishampel, P., and Harth, C.: Response of $\mathrm{CO}_{2}$ and $\mathrm{CH}_{4}$ emissions from peatlands to warming and water table manipulation, Ecol. Appl., 11, 311326, 2001.

Valentine, D. L. and Reeburgh, W. S.: New perspectives on anaerobic methane oxidation, Environ. Microbiol., 2, 477-484, 2000.

Valentine, D. L.: Biogeochemistry and microbial ecology of methane oxidation in anoxic environments: a review, A. Van. Leeuw., 81, 271-282, 2002.

van Breukelen, B. M. and Griffioen, J.: Biogeochemical processes at the fringe of a landfill leachate pollution plume: potential for dissolved organic carbon, $\mathrm{Fe}(\mathrm{II}), \mathrm{Mn}(\mathrm{II}), \mathrm{NH} 4$, and $\mathrm{CH}_{4}$ oxidation, J. Contam. Hydrol., 73, 181-205, 2004.

Vancleemput, O. and Baert, L.: Nitrite- a key compound in $\mathrm{N}$ loss 
processes under acid conditions, Plant Soil, 76, 233-241, 1984.

Vile, M. A., Bridgham, S., and Wieder, R. K.: Response of anaerobic carbon mineralization rates to sulfate amendments in a boreal peatland, Ecol. Appl., 13, 720-734, 2003.

Wake, L. V., Christopher, R. K., Rickard, P. A. D., Andersen, J. E., and Ralph, B. J.: A thermodynamic assessment of possible substrates for sulfate-reducing bacteria, Aust. J. Biol. Sci., 30, 115-172, 1977.

Ward, N., Larsen, O., Sakwa, J., Bruseth, L., Khouri, H., Durkin, A. S., Dimitrov, G., Jiang, L. X., Scanlan, D., Kang, K. H., Lewis, M., Nelson, K. E., Methe, B., Wu, M., Heidelberg, J. F., Paulsen, I. T., Fouts, D., Ravel, J., Tettelin, H., Ren, Q. H., Read, T., DeBoy, R. T., Seshadri, R., Salzberg, S. L., Jensen, H. B., Birkeland, N. K., Nelson, W. C., Dodson, R. J., Grindhaug, S. H., Holt, I., Eidhammer, I., Jonasen, I., Vanaken, S., Utterback, T., Feldblyum, T. V., Fraser, C. M., Lillehaug, J. R., and Eisen, J. A.: Genomic insights into methanotrophy: The complete genome sequence of Methylococcus capsulatus (Bath), Plos Biol., 2, 16161628,2004

Watson, A., Stephen, K. D., Nedwell, D. B., and Arah, J. R. M.: Oxidation of methane in peat: kinetics of $\mathrm{CH}_{4}$ and $\mathrm{O}_{2}$ removal and the role of plant roots, Soil Biol. and Biochem., 29, 1257 1267, 1997.

Watson, A. and Nedwell, D. B.: Methane production and emission from peat: the influence of anions (sulfate, nitrate) from acid rain, Atmos. Environ., 32, 3239-3245, 1998

Westbrook, C. J., Devito, K. J., and Allan, C. J.: Soil N cycling in harvested and pristine boreal forests and peatlands, Forest Ecol. Manage., 234, 227-237, 2006.

Westermann, P. and Ahring, B. K.: Dynamics of methane production, sulfate reduction, and denitrification in a permanently waterlogged alder swamp, Appl. Environ. Microbiol., 53, 2554 2559, 1987.

Whalen, S. C. and Reeburgh, W. S.: Methane oxidation, production, and emission at contrasting sites in a boreal bog, Geomicrobiol. J., 17, 237-251, 2000.
Whiting, G. J. and Chanton, J. P.: Primary production control of methane emission from wetlands, Nature, 364, 794-795, 1993.

Wieder, R. K. and Lang, G. E.: Cycling of inorganic and organic sulfur in peat from Big Run Bog, West Virginia, Biogeochemistry, 5, 221-242, 1988.

Wieder, R. K., Yavitt, J. B., and Lang, G. E.: Sulfur inputs may affect organic carbon balance of Sphagnum dominated wetlands, SCOPE (Scientific Committee on Problems of the Environment), 48, 119-124, 1992.

Yavitt, J. B., Lang, G. E., and Downey, D. M.: Potential methane production and methane oxidation rates in peatland ecosystems of the Appalachian Mountains, United States, Global Biogeochem. Cy., 2, 253-268, 1988.

Yavitt, J. B. and Lang, G. E.: Methane production in contrasting wetland sites: response to organic-chemical components of peat and to sulfate reduction, Geomicrobiol. J., 8, 27-46, 1990.

Yavitt, J. B., Williams, C. J., and Wieder, R. K.: Production of methane and carbon dioxide in peatland ecosystems across North America: effects of temperature, aeration, and organic chemistry of peat, Geomicrobiol. J., 14, 299-316, 1997.

Zehnder, A. J. and Brock, T. D.: Anaerobic methane oxidation: occurence and ecology, Appl. Environ. Microbiol., 39, 194-204, 1980.

Zehnder, A. J. B. and Brock, T. D.: Methane formation and methane oxidation by methanogenic bacteria, J. Bacteriol., 137, 420-432, 1979.

Zhu, G. B., Jetten, M. S. M., Kuschk, P., Ettwig, K. F., and Yin, C. Q.: Potential roles of anaerobic ammonium and methane oxidation in the nitrogen cycle of wetland ecosystems, Appl. Microbiol. Biot., 86, 1043-1055, 2010.

Zinder, S. H.: Physiological ecology of methanogens, in: Methanogenesis: ecology, physiology, biochemistry \& genetics, Chapman and Hall, New York, 128-206, 1993. 